\title{
The Federal Judiciary's Role in Drug Law Reform in an Era of Congressional Dysfunction
}

\author{
Erica Zunkel \& Alison Siegler*
}

\begin{abstract}
While state drug law reform is moving apace, federal drug law reform has moved much more slowly. Many, including the Judicial Conference of the United States and the United States Sentencing Commission, have urged Congress to enact substantive federal drug law reform for years. But Congress has not acted. As a result, the federal system continues to single out drug offenses for harsh treatment at the bail stage and the sentencing stage - the front end and back end of the federal mass incarceration crisis. In this paper, we argue that federal judges have a critical role to play in future federal drug law reform in light of Congress' long-standing failures to meaningfully change the laws. At the front end, judges should encourage the release of more people on bail by closely scrutinizing prosecutors' motions for temporary detention and giving little weight to the Bail Reform Act's presumption of detention. Data shows that the statutory drug presumption is overbroad and does a poor job of determining who is a risk of flight or a danger to the community. At the back end, judges should issue categorical policy disagreements with the drug sentencing guidelines and the career offender sentencing guideline using the Supreme Court's blueprint in Kimbrough v. United States. Judges should issue sentences below these guidelines because they are not based on empirical evidence, over-punish drug offenses, and result in racial disparities. At both ends, judges should rest their decisions on the evidence that the drug presumption, the drug sentencing guidelines, and the career offender sentencing guideline are flawed. While judicial action is not a cure for Congressional inaction, it would send a clear message from one co-equal branch of government to another that substantive reform is urgently needed.
\end{abstract}

* Erica Zunkel is an Associate Clinical Professor of Law and Associate Director of the Federal Criminal Justice Clinic at the University of Chicago Law School. Alison Siegler is a Clinical Professor of Law and the Founder and Director of the Federal Criminal Justice Clinic at the University of Chicago Law School. Thank you to George Colligan, Stephanie Didwania, Jelani Jefferson Exum, Amy Kimpel, Adam Simon, and Jonathan Wroblewski for thoughtful comments and Carly Gibbons for helpful research assistance. 


\section{INTRODUCTION}

From progressive prosecutors diverting drug cases out of the criminal legal system to the elimination of mandatory minimums and three strikes laws, drug law reform in the states is having a moment. Some have even gone so far as to suggest that the War on Drugs is coming to an end. ${ }^{1}$ Federal drug law reform has moved much more slowly. ${ }^{2}$ To be sure, there has been modest progress. In late 2018, President Donald Trump signed the First Step Act ("FSA") into law- the most significant reform of our federal drug laws since Congress passed the Anti-Drug Abuse Act in 1986 ("1986 Act"). Among other things, the FSA reduced the draconian recidivist enhancements for federal drug offenses, expanded the "safety valve" so judges have more latitude to sentence low-level, nonviolent drug offenders below the mandatory minimum, ${ }^{3}$ and mandated correctional reform and rehabilitative programming in the Bureau of Prisons. ${ }^{4}$

While these reforms made some progress, they simply tinker around the edges and do not come close to ending the War on Drugs or solving the federal mass incarceration crisis. Many, including the Judicial Conference of the United States and the United States Sentencing Commission, have urged Congress to enact more sweeping reforms for years. But Congress has not acted. In the meantime, the federal system's decades-long obsession with singling out people charged and convicted of drug offenses for harsh treatment continues.

The federal system's preoccupation with drug offenses has significant consequences at the bail stage and the sentencing stage - the front end and back end of the federal mass incarceration crisis.

Federal law treats drug offenses harshly from the outset, starting at a person's initial appearance before a federal judge. The Bail Reform Act ("BRA") — passed at the height of the War on Drugs in the 1980s - allows prosecutors to move to temporarily detain almost anyone who is charged with a drug offense until a

1 See Alex Kreit, Drug Truce, 77 Оніо ST. L.J. 1323, 1324 (2016) (describing efforts by President Barack Obama's drug "czars" to retire the War on Drugs "concept"); Nicholas Kristof, Seattle Has Figured Out How to End the War on Drugs, N.Y. TimEs (Aug. 23, 2019), https://www.nytimes.com/2019/08/23/opinion/sunday/opioid-crisis-drug-seattle.html.

2 See, e.g., Kara Gotsch, Breakthrough in U.S. Drug Sentencing Reform: The Fair Sentencing Act and the Unfinished Reform Agenda, WOLA 1, 1 (Nov. 2011), https://www.wola.org/ sites/default/files/downloadable/Drug\%20Policy/2011/FSA/WOLA_RPT_FSA-Eng_FNL-WEB.pdf. ("The Fair Sentencing Act was welcomed by civil rights and community activists, but the compromise measure fell short of the changes they had sought for two decades.").

3 The changes to the recidivist enhancements and the "safety valve" are prospective only and do not provide relief to those who were sentenced prior to the Act's passage. First Step Act of 2018, Pub. L. No. 115-391, § 756, 132 Stat. 5194, 5221 (2018).

4 See id. 
detention hearing. ${ }^{5}$ At the detention hearing, the BRA mandates a presumption that those same people be detained throughout the case based on dangerousness, even though they are presumed innocent. ${ }^{6}$ The BRA's provisions favoring pretrial detention in drug cases are outdated relics of the War on Drugs and should be eliminated. Data shows that the drug presumption does not accurately predict which arrestees pose a flight risk or a danger to the community, the two pillars of the BRA.

The federal judiciary has already voiced its opposition to the drug presumption, which alone should be a clarion call to judges to exercise their discretion to release people in presumption cases. In 2017, the Judicial Conference - chaired by Chief Justice John Roberts - urged Congress to eliminate the presumption of detention in most drug cases. ${ }^{7}$ The Judicial Conference reiterated this recommendation during the COVID-19 pandemic and issued a broader call for federal bail reform: "Legal, policy, and budgetary factors-including the presumption of innocence and the relative costs of incarceration versus pretrial supervision-support reducing unnecessary pretrial detention." Congress' inaction in the face of the judiciary's repeated calls for reform makes it all the more imperative that judges use their discretion to counteract the unwarranted harshness of the presumption in drug cases.

Federal law also treats drug offenses harshly at the sentencing stage. The majority of federal drug offenses carry mandatory minimum penalties that judges must impose - no matter how compelling the case or mitigating the circumstancesunless the person provides "substantial assistance" or qualifies for the "safety valve." Like the BRA, Congress passed these laws in the 1980s, when fear about

$5 \quad 18$ U.S.C. $\$ 3142(\mathrm{f})(1)(\mathrm{C})$ provides that prosecutors can move for temporary detention in any case that involves "an offense for which a maximum term of imprisonment of ten years or more is prescribed in the Controlled Substances Act (21 U.S.C. 801 et seq.), the Controlled Substances Import and Export Act (21 U.S.C. 951 et seq.), or chapter 705 of Title 46 [46 USCS § 70501 et seq.]." 18 U.S.C. $§ 3142(f)(1)(C)(2008)$. This encompasses nearly all federal drug offenses.

$6 \quad$ See 18 U.S.C. $\$ 3142(\mathrm{e})(3)(\mathrm{A})(2008)$.

7 See Report of the Proceedings of the Judicial Conference of the United States 1011 (Sept. 2017), https://www.uscourts.gov/sites/default/files/17-sep_final_0.pdf [hereinafter JUDICIAL CONFERENCE REPORT].

8 See Letter from the Judicial Conference of the United States to the House and Senate Appropriations Committees, Enclosure 2 at 2 (Apr. 28, 2020), [hereinafter 2020 Judicial Conference Letter].

9 Approximately $66 \%$ of all drug trafficking cases in Fiscal Year 2019 carried a mandatory minimum penalty. U.S. Sentencing COMM'N, MANDATORY Minimum Penalties IN Drug TRAFFICKING CASES-Fiscal YeAR 2019 122, Figure D-2 (2019), https://www.ussc.gov/sites/default/files/pdf/research-and-publications/annual-reports-and-

sourcebooks/2019/FigureD2.pdf. Of those cases, $42.2 \%$ received no relief from the mandatory minimum penalty at all, while $17 \%$ received relief for providing "substantial assistance" and 31\% received relief for satisfying the requirements for the "safety valve." $I d$. Prosecutors "have virtually total discretion to make one or both motions." Mark W. Bennett, A Slow Motion Lynching? The War on Drugs, Mass Incarceration, Doing Kimbrough Justice, and a Response to Two Third Circuit Judges, 66 RUTGERS L. REV. 873, 885 (2014). 
crime and drugs was at its apex. While mandatory minimums have been roundly criticized across the political spectrum and there is clear evidence they do not work, ${ }^{10}$ they remain on the books because Congress has not mustered the political will to meaningfully reform or eliminate them.

Beyond the mandatory minimums, people charged with federal drug offenses often face even higher sentences under the drug sentencing guidelines, which primarily focus on drug type and quantity in setting the punishment. ${ }^{11}$ Finally, if someone charged with a drug offense has been convicted of more than one felony drug offense in the past, they face a still-higher sentence under the career offender sentencing guideline, even though the Sentencing Commission recently urged Congress to amend the law to exclude "drug trafficking only" career offenders. ${ }^{12}$

The statistics highlight how the laws that apply to drug cases at bail and sentencing have contributed to mass incarceration and racial injustice. Today, drug offenses make up nearly 30\% of the federal docket nationwide. ${ }^{13}$ From 1990 to 2008, that percentage was even higher-varying from approximately $35 \%$ to as high as $47 \% .{ }^{14}$ In contrast, when the BRA and the 1986 Act were enacted, drug offenses

10 See, e.g., The Pew Charitable Trusts, Federal Drug Sentencing Laws Bring High Cost, Low Return, 3-4 (Aug. 27, 2015), https://www.pewtrusts.org/en/research-and-analysis/issuebriefs/2015/08/federal-drug-sentencing-laws-bring-high-cost-low-return (despite decades of mandatory minimum drug laws, drug prices have declined while drug use and purity have increased); U.S. Sentencing Comm'n, Cocaine And Federal Sentencing Policy 66 (2002), https://www.ussc.gov/sites/default/files/pdf/news/congressional-testimony-and-reports/drugtopics/200205-rtc-cocaine-sentencing-policy/200205_Cocaine_and_Federal_Sentencing_Policy.pdf ("The declining prices for powder cocaine during the period of increasing penalties appear inconsistent with a deterrent effect of federal cocaine penalties."); Eduardo Porter, Numbers Tell of Failure in Drug War, N.Y. TiMES (July 3, 2012), https://www.nytimes.com/2012/07/04/business/in-rethinking-thewar-on-drugs-start-with-the-numbers.html; Tanya Golash-Boza, America's Mass Incarceration Problem in 5 Charts-or, Why Sessions Shouldn't Bring Back Mandatory Minimums, THE CONVERSATION (May 29, 2017), https://theconversation.com/americas-mass-incarceration-problemin-5-charts-or-why-sessions-shouldnt-bring-back-mandatory-minimums-78019.

11 See U.S. Sentencing Guidelines Manual § 2D1.1(c) (U.S. Sentencing Comm’n 2018) (drug quantity table).

12 See U.S. Sentencing Comm'n, Report to the Congress: Career OfFender Sentencing ENHANCEMENTS (2016), https:/www.ussc.gov/sites/default/files/pdf/news/congressional-testimonyand-reports/criminal-history/201607_RtC-Career-Offenders.pdf [hereinafter 2016 CAREER OFFENDER REPORT].

13 U.S. Sentencing Comm'n, 2019 Annual Report and Sourcebook of Federal SENTENCING STATISTICS 45 (2019), https:/www.ussc.gov/sites/default/files/pdf/research-andpublications/annual-reports-and-sourcebooks/2019/2019-Annual-Report-and-Sourcebook.pdf [hereinafter 2019 ANNUAL REPORT].

14 See U.S. Sentencing COMm'N, Sourcebook ArChives, https://www.ussc.gov /research/sourcebook/archive. The online Archives start in 1996. Pre-1996 statistics are found in the Commission's Annual Reports. See U.S. Sentencing Comm'n, Annual Reports Archives, https://www.ussc.gov/about/annual-report/archive. 
constituted just $18 \%$ of the federal docket, ${ }^{15}$ and fraud and regulatory crimes dominated. ${ }^{16}$ At the bail stage, judges detain people charged with drug offenses at an astonishingly high rate. A 2017 government study found that the presumption of detention applied in $93 \%$ of all federal drug cases, even though it was intended to apply to rich drug traffickers who could buy their way out of jail. ${ }^{17}$ From 1995 to 2010 , the percentage of people charged with federal drug offenses who were jailed while awaiting trial increased from $76 \%$ to $84 \% .{ }^{18}$ At the back end, at sentencing, it is a virtual certainty that anyone convicted of a federal drug offense will spend time behind bars: $96.3 \%$ of drug offenders were sentenced to prison in Fiscal Year 2019 and approximately $66 \%$ were convicted of an offense that carried a mandatory minimum penalty. ${ }^{19}$ The average sentence was 76 months, but varied by drug type. ${ }^{20}$ These trends have remained stable over time. ${ }^{21}$

Moreover, in the years since the BRA and the 1986 Act were passed, people of color have borne the brunt of these harsh federal drug laws. At the bail stage, people of color are detained before trial at a higher rate than whites, even after controlling for other factors that are predictive of detention or release. ${ }^{22}$ At the sentencing stage, troubling racial disparities exist as well. The most recent Sentencing Commission data shows that in Fiscal Year 2019, fully $75 \%$ of those sentenced for federal drug offenses were people of color: $44.3 \%$ were Hispanic and $27.4 \%$ were Black. ${ }^{23}$ By

15 Administration of Bail by State and Federal Courts: A Call for Reform: Hearing Before the Subcomm. On Crime, Terrorism, and Homeland Security of the H. Comm. On the Judiciary, 115th Cong. 16 (2019), https://docs.house.gov/meetings/JU/JU08/20191114/110194/HHRG-116-JU08Wstate-SieglerA-20191114.pdf [hereinafter Siegler Written Statement] (citing John Scalia, Federal Drug Offenders, 1999 with Trends 1984-99, U.S. Dep't of Justice Bureau of Justice Statistics Special Report at 1 (Aug. 2001), https://www.Csdp.org/research/fdo99.pdf) (Written Statement of Alison Siegler).

16 Thomas H. Cohen \& Amaryllis Austin, Examining Federal Pretrial Release Trends Over the Last Decade, 82 Fed. Probation 3, 4 (2018).

17 See Amaryllis Austin, The Presumption for Detention Statute's Relationship to Release Rates, 81 Fed. Probation 52, 55 (2017).

$18 \quad I d$. at 53.

192019 AnNUAl RePORT, supra note 13, at 62, Table 13, 122, Figure D-2. The $96.3 \%$ figure excludes the 563 people convicted of drug possession - a rare charge in the federal system. $I d$. at 62 .

20 Id. at 64 , Table 15.

21 See U.S. Sentencing Comm'n, Sourcebook Archives, https://www.ussc.gov/research/ sourcebook/archive.

22 Stephanie Holmes Didwania, Discretion and Disparity in Federal Detention, 115 Nw. U.L. REV. (forthcoming 2021) (detailing the results of an empirical study of 300,000 federal cases from 2002 to 2016).

232019 AnNUAL RePORT, supra note 13, at 110, Table D-2. 
comparison, the general population is $18.5 \%$ Hispanic and $13.4 \%$ Black. ${ }^{24}$ Data also shows that people of color ultimately face longer prison terms than whites arrested for the same offenses with the same prior records. ${ }^{25}$ For example, the Sentencing Commission recently found that when Black men and White men commit the very same crime, Black men on average receive a sentence that is nearly $20 \%$ longer. $^{26}$ Some of this is certainly a result of mandatory minimum charging, which "introduces sizeable racial disparities" into the system. ${ }^{27}$ Data also shows that Black people who are convicted of a federal drug offense carrying a mandatory minimum are least likely to receive a sentence below the minimum. ${ }^{28}$

In this paper, we argue that federal judges have a critical role to play in future federal drug law reform in light of Congress' long-standing failures to meaningfully change the laws. Judges can use their considerable discretion at both stages to counteract the unwarranted harshness of these laws and ameliorate the racial disparities. At both ends, judges should emphasize the evidence that the pretrial drug presumption, the drug sentencing guideline, and the career offender sentencing guideline are flawed. ${ }^{29}$ While judicial action is not a cure for Congress' inaction, it

24 U.S. Census BurEau, QuiCK FACTS 2019, https://www.census.gov/quickfacts/fact/table/ US/PST045219.

25 See Sonja B. Starr \& M. Marit Rehavi, Racial Disparity in Federal Criminal Sentences, 122 J. Pol. ECON. 1320, 1349 (2014); Written Submission of the American Civil Liberties Union on Racial Disparities in Sentencing: Hearing on Reports of Racism in the Justice System of the United States, 153rd Session Inter-Am. Comm'n on Hum. Rts 1, 1-2 (2014) [hereinafter ACLU Written Submission]; Bennett, supra note 9, at 881-82 (chronicling the demographics of crack cocaine defendants in federal court and noting that "[n] early $83 \%$ of the . . . crack defendants sentenced in 2012 were black").

26 U.S. Sentencing Comm’n, Demographic Differences in Sentencing: An Update to the 2012 BOOKER REPORT 2 (2017), https://www.ussc.gov/sites/default/files/pdf/research-and-publication s/research-publications/2017/20171114_Demographics.pdf.

27 Sonja B. Starr \& M. Marit Rehavi, Mandatory Sentencing and Racial Disparity: Assessing the Role of Prosecutors and the Effects of Booker, 123 YALE L.J. 2, 10 (2013) (“Our research suggests that prosecutorial decisions are important sources of [racial] disparity - especially the decision to file mandatory minimum charges, which are prosecutors' most powerful tools for constraining judges.").

28 U.S. Sentencing Comm'n, Mandatory Minimum Penalties in the Federal Criminal JustiCE SYSTEM 8 (2017), https://www.ussc.gov/sites/default/files/pdf/research-and-publications/ research-publications/2017/20171025_Drug-Mand-Min.pdf [hereinafter 2017 MANDATORY MINIMUM REPORT].

29 In 2015, Federal District Judge Jed Rakoff called for judges to speak out about mass incarceration, mandatory minimums, and the sentencing guidelines. "What is called for in such circumstances is leadership: those whom the public does respect should point out why statutes prescribing mandatory minimums, draconian guidelines, and the like are not the solution to controlling crime, and why, in any case, the long-term price of mass incarceration is too high to pay, not just in economic terms, but also in terms of shared social values." Jed S. Rakoff, Mass Incarceration: The Silence of the Judges, N.Y. REv. OF BoOKS (May 15, 2015), https://www.nybooks.com/ articles/2015/05/21/mass-incarceration-silence-judges/. 
would send a clear message from one co-equal branch of government to another that substantive reform is urgently needed. ${ }^{30}$

At the front end, judges should encourage the pretrial release of more people by closely scrutinizing prosecutors' motions for temporary detention at the initial appearance stage and giving little weight to the drug presumption of detention at the detention hearing stage.

At the back end, judges should issue categorical policy disagreements with the drug sentencing guidelines and the career offender sentencing guideline using the Supreme Court's blueprint in Kimbrough v. United States. ${ }^{31}$ These guidelines are not based on empirical evidence and national experience, and therefore do not exemplify the Sentencing Commission's "exercise of its characteristic institutional role." 32 Accordingly, they warrant less respect and adherence than other guidelines.

This article proceeds in four parts. Part I discusses the front-end problem-the Bail Reform Act of 1984s provisions that favor pretrial detention for people charged with federal drug offenses. Part II discusses the back-end problem - the history of drug mandatory minimums and the drug sentencing guidelines, including the career offender guideline. Part III discusses attempts to reform the federal pretrial detention system and federal drug laws and situates them within current efforts to reform the criminal legal system. Part IV concludes by discussing how judges can advance reform at bail and sentencing.

\section{THE BAIL REFORM ACT OF 1984’s MisGUIDED FoCUS ON FEDERAL DRUG OFFENSES}

The Eighth Amendment to the Constitution mandates that "[e]xcessive bail shall not be required." 33 Congress enacted the first federal bail provision as part of the Judiciary Act of 1789, and for nearly 200 years, the federal bail system "was premised on a defendant's right to bail for all non-capital offenses if the defendant could post sufficient sureties." ${ }^{34}$ But because release was based on a person's financial resources, people who were indigent had few options for release. ${ }^{35}$ Those

$30 \quad I d$. ("[W]hile this treatment is mandated by the legislature, it is we judges who mete it out. Unless we judges make more effort to speak out against this inhumanity, how can we call ourselves instruments of justice?").

$31 \quad 552$ U.S. 85 (2007).

32 Id. at 109.

33 U.S. CONST. amend. VIII.

34 Austin, supra note 17, at 52; see also Alexa Van Brunt \& Locke E. Bowman, Toward a Just Model of Pretrial Release: A History of Bail Reform and a Prescription for What's Next, 108 J. CRIM. L. \& CRIMINOLOGY 701, 710 (2018) ("In the colonial era, bail was generally synonymous with release.").

35 Austin, supra note 17, at 52; see also Van Brunt \& Bowman, supra note 34, at 724 ("Bail reform gained momentum throughout the decade. The National Conference on Bail and Criminal 
concerns led to the passage of the Bail Reform Act of 1966, which created a presumption of release without financial conditions and focused a judge's bail determination on non-appearance for court hearings. ${ }^{36}$ Dangerousness was not a consideration. ${ }^{37}$

The Bail Reform Act of 1966 was "a progressive step forward" because it "disfavored wealth-based distinctions" and highlighted "the importance of individualized decision-making" at the bail stage. ${ }^{38}$ As a result, pretrial release rates increased throughout the $1970 \mathrm{~s}^{39}$ This progress was temporary, however, as the country "entered an era defined by tough-on-crime rhetoric and related legislative action." ${ }^{40}$ In the 1980 s, legislators became myopically focused on violent crime and keeping violent offenders off the streets. ${ }^{41}$ For example, Senator Lawton Chiles referred to a "crime wave" that diminished the public's confidence "in the ability of our courts to deal with criminals," during hearings on the BRA. ${ }^{42} \mathrm{He}$ traced the public's supposed lack of confidence to the bail system: "[T]he way it operates today does as much as any other criminal justice procedure to foster that lack of confidence in our courts." ${ }^{43} \mathrm{He}$ urged Congress to pass bail reform that permitted judges to consider dangerousness. ${ }^{44}$ The Department of Justice took the same position. ${ }^{45}$

That view won out, and the federal bail framework changed dramatically with Congress' passage of the BRA in 1984, at the height of the War on Drugs. Instead of focusing solely on whether a person posed a risk of flight, the BRA permitted

Justice, held in the spring of 1964 , focused on alternatives to money bail with the purpose of eliminating the intentional detention of the poor.").

36 Austin, supra note 17, at 52; Federal Bail Procedures Hearings Before the Subcommittee on Constitutional Rights and the Subcommittee on Improvements in Judicial Machinery of the Committee on the Judiciary United States Senate, 89th Cong. 5, 33 (1965) (text of s. 1357).

37 See Austin, supra note 17, at 52.

38 Van Brunt \& Bowman, supra note 34, at 725-26.

39 See id. at 725.

40 See id. at 730.

41 See id. at 731.

42 Hearings Before the Subcommittee on the Constitution of the Committee on the Judiciary, 97th Cong. 59 (1981), at 56 [hereinafter 1981 Hearings] (Statement of Hon. Lawton Chiles, a U.S. Senator from the State of Florida).

43 Id.

$44 \quad$ Id. at 57.

45 Id. at 156 (Statement of Jeffrey Harris, Deputy Associate Attorney General of the United States) (testifying that in order "to provide an adequate mechanism to deal with the dangerous defendants who are seeking release," courts "must be given the authority to order the detention of those defendants who are so dangerous that no condition of release will reasonably assure the safety of the community or other persons"). 
judges to consider future dangerousness when making a release decision. ${ }^{46}$ The Supreme Court concluded that the BRA was constitutional even with the new focus on dangerousness, emphasizing that release was the "norm" and detention "the carefully limited exception." 47

The BRA made two important changes that target people charged with drug offenses for pretrial detention. At the initial appearance stage, the BRA authorizes mandatory temporary detention at the government's request. ${ }^{48}$ At the detention hearing stage, the BRA mandates a rebuttable presumption that the person be detained throughout the case. ${ }^{49}$ Both provisions apply to any drug offense that carries a maximum term of imprisonment of ten years or more. Virtually all federal drug offenses subject individuals to these heightened detention standards. They apply to all offenses involving a hard drug and any marijuana offense involving 50 or more kilograms, and they apply without regard to a person's role, culpability in the offense, or lack of prior convictions. ${ }^{50}$ Thus, these detention provisions sweep up alleged drug kingpins and low-level mules alike, and fall as heavily on first offenders as on those with long rap sheets. ${ }^{51}$

The drug presumption has had a significant impact on pretrial detention in federal drug cases. The fact that the presumption applied in $93 \%$ of all federal drug cases $^{52}$ is a direct consequence of the 1980s anti-drug sentiment: "[T]he presumptions were ... created in the midst of the 'War on Drugs'; therefore, the cases targeted by these presumptions were largely drug offenses." ${ }^{\text {. }}$ The presumption has also resulted in extremely high detention rates. While just $16 \%$ of people charged with federal drug offenses were released pretrial in $2013,{ }^{54}$ people charged with state-level felony drug offenses in large urban areas were released $65 \%$

46 Austin, supra note 17, at 53; see also Marc Miller \& Martin Guggenheim, Pretrial Detention and Punishment, 75 MinN. L. REV. 335, 346 (1990) ("The Bail Reform Act of 1984 makes protection of the public the pivotal factor in determining whether to release or detain federal defendants.").

47 United States v. Salerno, 481 U.S. 739, 755 (1987).

48 See 18 U.S.C. $\S 3142(\mathrm{f})(1)(\mathrm{C})(2008)$.

49 See 18 U.S.C. $\S 3142(\mathrm{e})(3)(\mathrm{A})(2008)$.

$50 \quad$ See 21 U.S.C. $\S \S 841(b), 960(b)$ (2018).

51 See Siegler Written Statement, supra note 15, at 17; Reevaluating the Effectiveness of Mandatory Minimum Sentences: Hearing Before the S. Comm. on the Judiciary, 113th Cong. 225-26 (2013) (Written Statement of the Federal Criminal Justice Clinic at the University of Chicago Law School).

\footnotetext{
52 Austin, supra note 17, at 55.

53 Cohen \& Austin, supra note 16, at 4.

54 Austin, supra note 17, at 53.
} 
of the time in $2009 .{ }^{55}$ These state release rates are likely to be even higher today given the bail reform movement sweeping the country. ${ }^{56}$

While much has been written about the BRA generally, the legislative history of the drug presumption of detention has not been explored in depth. That debate is illustrative of just how far the presumption has strayed from its original purpose. A close look at the BRA's legislative history demonstrates that Congress did not intend the drug presumption to apply so broadly. Rather, legislators wanted the drug presumption to prevent rich people suspected of high-level drug trafficking from fleeing to avoid prosecution. ${ }^{57}$ When the BRA was debated, drug prosecutions were not nearly as prevalent as they are today and therefore the drug presumption would not have affected "a majority of cases." 58 Of course, as drug prosecutions increased exponentially over the next decades, the presumption became more central to detention decisions. ${ }^{59}$

As legislators debated changes to the BRA that would favor pretrial detention in drug cases, they used hyperbolic language to describe the country's drug problem. That language reflected the 1980s War on Drugs mentality. ${ }^{60}$ Senator Lawton Chiles, who hailed from Florida, stated that the BRA required "specially crafted" provisions to "ensure that those who are responsible for the drug problem which has swept this country are brought to justice." ${ }^{16}$ Senator Orrin Hatch, without citing any evidence, contended that bail reform in drug cases was needed because drug offenders "historically abused bail proceedings more than most criminal offenders."

Senator Chiles was one of the most forceful proponents for adding a presumption of detention in drug cases. ${ }^{63} \mathrm{He}$ believed that drug trafficking cases posed a "special problem" because of "a revolving door situation" where people

55 Brian A. Reaves, Federal Defendants in Large Urban Counties, 200-Statistical Tables, U.S. Dep't of Justice Bureau of Justice Statistics, at 15 (Dec. 2013), https://www.bjs.gov/ content/pub/pdf/fdluc09.pdf.

56 Stephanie Wykstra, Bail Reform, Which Could Save Millions of Unconvicted People From Jail, Explained, Vox (Oct. 17, 2018), https://www.vox.com/future-perfect/2018/10/17/17955306/bailreform-criminal-justice-inequality.

57 This idea stems from discussions with Jennesa Calvo-Friedman of the American Civil Liberties Union.

58 Cohen \& Austin, supra note 16, at 4.

59 Id.

60 See, e.g., Eric E. Sterling, The Sentencing Boomerang: Drug Prohibition Politics and Reform, 40 ViLL. L. REV. 383, 398 (1995) (discussing how by the 1980s "the hyperbole of the "drug war'-really a kind of 'drug market civil war'—was used evermore irresponsibly.”).

611981 Hearings, supra note 42, at 59.

62 Id. at 56.

63 Id. at $56-57$. 
were released on bond and then failed to appear in court. ${ }^{64} \mathrm{He}$ used his own state of Florida as an example. He claimed that the "massive invasion of illicit drugs" there enabled drug dealers to reap proceeds from $\$ 7$ billion to $\$ 10$ billion a year. ${ }^{65}$ Such large amounts of cash meant that "no matter how high bail is set, the drug smuggler who has been arrested will make bail" and "will never appear in court." ${ }^{\text {"66 }}$ For these "drug smuggler[s]," bail forfeiture was "no more than a temporary business loss." 67 Accordingly, Chiles believed that allowing judges to consider dangerousness at the bond stage was not enough to "solve the special problem of drug dealers" and insisted that legislators also add a presumption of detention. ${ }^{68}$

Chiles explained that a presumption of detention would establish "special considerations" for bail in drug cases that would "go a long way toward closing that revolving door and would help assure that drug dealers who are arrested are brought to justice." ${ }^{69}$ The presumption would operate so that the person "should not be given bail unless he could show mitigating factors." ${ }^{, 70}$ Chiles believed that the presumption of detention would provide judges with "more direction" in making bond determinations in drug cases, ultimately "denying bail to drug dealers in many instances." 71

Other legislators and the Department of Justice echoed Chiles' concerns. The Senate Judiciary Committee, chaired by Senator Strom Thurmond, argued that there should be a presumption of detention for the "most serious" drug offenses because it is "well known that drug trafficking is carried on to an unusual degree by persons engaged in continuing patterns of criminal activity" and they "have both the resources and foreign contacts to escape to other countries with relative ease." ${ }^{72}$ In his 1984 testimony, Deputy Attorney General James Knapp emphasized that detention was appropriate for "major drug traffickers" because drug fugitives outnumbered federal drug agents. ${ }^{73}$ He noted that some "drug figures" were "even

64 Id. at 57; see also JAMES FORMAN, JR., LOCKING UP OUR OwN 127 (2017) (one of the reasons the Black community in Washington, D.C. supported tougher drug laws in the 1980s was the perception of "excessive leniency" at the bail stage).

651981 Hearings, supra note 42, at 57.

66 Id.

67 Id.

681981 Hearings, supra note 42, at 59.

$69 \quad I d$. at 58.

$70 \quad I d$.

71 Id. at 59, 62 .

72 The Bail Reform Act of 1983: Report of the Committee on the Judiciary United States Senate on S. 215, 98th Cong., S. REP. No. 98-147 (1983), at 46.

73 Hearings Before the Subcommittee on Courts, Civil Liberties, and the Administration of Justice of the Committee on the Judiciary, 98th Cong. 191 (1984), at 191 [hereinafter 1984 Hearings] 
adopting the practice of setting aside a portion of their illegal proceeds" to pay bail forfeitures. ${ }^{74}$

The BRA's legislative history shows that legislators were shortsighted about the implications of the drug presumption. For his part, Knapp foreshadowed that the drug presumption would apply even to those "without any prior record or evidence of criminal history." 75 But that was not on legislators" radar. By focusing on "major drug traffickers" at a time when drug cases made up a small percentage of the federal docket, legislators do not appear to have contemplated - or cared - that the drug presumption would sweep too broadly.

Today, the problems with the drug presumption are clear and well documented. $^{76}$ The presumption applies equally to first offenders and people charged with low-level, nonviolent drug offenses, it leads to high detention rates, and falls most heavily on people of color. Judges have a responsibility to use their discretion to mitigate these injustices.

\section{THE EVOLUTION OF MANDATORY MINIMUMS AND SENTENCING GUIDELINES FOR FEDERAL DRUG OFFENSES}

As with the federal bail regime, the legislative, executive, and judicial branches each has a hand in the federal sentencing regime. Congress passes laws that set minimum and maximum penalties for drug offenses, prosecutors determine what charges to file, and the Sentencing Commission - an independent agency housed in the judicial branch-determines the sentencing guidelines that are the "starting point" for judges at sentencing. ${ }^{77}$ But Congress' laws, most notably mandatory minimum sentencing statutes, ultimately trump the Commission's guidelines. What

(Testimony of James I.K. Knapp, Deputy Assistant Att'y Gen., Criminal Division, on Behalf of the U.S. Department of Justice).

74 Id. at 191.

75 Id. at 256

76 In a June 1, 1984 letter to the House of Representatives Subcommittee on Courts, Civil Liberties, and the Administration of Justice, the Department of Justice downplayed the "costs" of adopting a bail regime that considered danger to the community, writing that "the number of persons who are so dangerous as to warrant pretrial detention in the federal system is small." 1984 Hearings, supra note 73, at 313 (Letter of Deputy Assistant Attorney General James Knapp).

77 See Gall v. United States, 552 U.S. 38, 49 (2007). 
follows is an overview of how mandatory minimums and the guidelines evolved and how they operate in tandem and tension today.

\section{A. The Controlled Substances Act \& Federal Drug Mandatory Minimums}

Drug mandatory minimums date back to the early twentieth century, and have often been linked to fears about race and crime. ${ }^{78}$ The first mandatory minimum was passed in 1914, when Congress set a five-year minimum for manufacturing opium for smoking purposes. ${ }^{79}$ The law was influenced by widespread anti-Chinese sentiment. For example, in 1902, the American Pharmaceutical Association's Committee on the Acquirement of the Drug Habit blamed Chinese immigrants for "importing" opium smoking to the United States. The Committee concluded, "If the Chinaman cannot get along without his 'dope,' we can get along without him."

More mandatory minimums followed until the 1970s when politicians began to recognize that mandatory minimums were not working. Then-Congressman George H.W. Bush spoke in favor of repealing mandatory minimum drug laws because it would "result in better justice and more appropriate sentences." ${ }^{11}$ The Controlled Substances Act ("CSA"), passed in 1970, was a radical departure from prior drug laws. It eliminated all mandatory minimums, except those relating to drug kingpins. ${ }^{82}$ It also imposed a "unified legal framework" to regulate drugs ${ }^{83}$ Under the CSA, drugs were grouped "based on their accepted medical uses, the potential for abuse, and their psychological and physical effects on the body." ${ }^{84}$ Drugs in Schedule 1, such as marijuana, cocaine, and methamphetamine, were categorized as such because "of their high potential for abuse, lack of any accepted medical use, and the absence of any accepted safety for use in medically supervised treatment." 85

78 Mona Lynch, Hard Bargains: The Coercive Power of Drug Laws in Federal Court 15 (2016).

79 See Harrison Narcotics Tax, Pub. L. No. 63-223, 38 Stat. 278 (1914).

80 Jeff Goldberg \& Dean latimer, Flowers in the Blood: The Story of Opium 210 (2014).

81 Molly M. Gill, Correcting Course: Lessons from the 1970s Repeal of Mandatory Minimums, 21 FED. SENT'G REP. 55, 55 (2008).

82 See Charles Doyle, Cong. Research Ser., R45074, Mandatory Minimum Sentencing FOR FEDERAL DRUG OFFENSES 2 (2018).

83 Joanna R. Lampe, Cong. Research Ser., R45948, The Controlled Substances Act (CSA): A LEGAL OVERVIEW FOR THE 116TH CONGRESS 2 (2019).

84 Gonzales v. Raich, 545 U.S. 1, 13 (2005).

85 Id. at 14. 
The purported objectives of the CSA were "to conquer drug abuse and to control the legitimate and illegitimate traffic in controlled substances." 86

The pendulum swung back in favor of mandatory minimum sentencing with the rise of the crack cocaine "epidemic." Crack cocaine was widely seen as devastating Black communities in urban cities ${ }^{87}$ The media devoted story after story to "crack babies" and "gangbangers." 88 The overdose death of basketball star Len Bias-ironically from powder cocaine, not crack cocaine as first reported by the media $^{89}$ - was all that it took for Congress to act, and overreact. ${ }^{90}$

With haste, Congress passed the 1986 Act, which established the framework for the current federal mandatory minimum drug laws. The Act set five- and tenyear mandatory minimum sentences for most drug offenses based on the type and quantity of the drug. ${ }^{91}$ Those mandatory minimums could be increased to 10 or 20 years if the person had been convicted of a felony drug offense in the past. ${ }^{92}$ Two years later, legislators passed a three-strikes law for drugs: if a person was subject to a 10-year mandatory minimum and had two prior drug convictions, the government could seek a jaw-dropping mandatory minimum sentence of life. ${ }^{93}$ The 1986 Act also established the 100-to-1 crack/powder cocaine sentencing disparity that was on the books until the Fair Sentencing Act of 2010 reduced it to 18 -to-1. ${ }^{94}$

86 Id. at 12.

87 Forman, supra note 64, at 156 ("In the magnitude of the threat it posed to black America, the crack epidemic exceeded even the heroin crisis of the late 1960s.").

88 See Michelle Alexander, The New Jim Crow: Mass Incarceration in The Age of COLORBLINDNESS 52-53 (2010).

89 John Schuppe, 30 Years After Basketball Star Len Bias' Death, Its Drug War Impact Endures, NBC News (June 19, 2016), https://www.nbcnews.com/news/us-news/30-years-afterbasketball-star-len-bias-death-its-drug-n593731.

90 See U.S. Sentencing Comm'N, 1995 Report to the Congress: Cocaine and Federal Sentencing Policy (1995), http://www.ussc.gov/report-cocaine-and-federal-sentencing-policy-2.

91 Kimbrough v. United States, 552 U.S. 85, 95 (2007).

92 See 21 U.S.C. $\S \S 841,851$ (2007); Lynch, supra note 78, at 26.

93 Lynch, supra note 78, at 26. The Third Strike Project highlights the heartbreaking injustices of the federal three strikes drug law, which Congress eliminated in the FSA. "The law requires the judge to impose a life sentence in drug cases — even when the judge believes a life sentence is excessive. For many judges, the 3 Strikes Law is a crisis of conscience. A number of federal judges - powerless from the bench-have spoken out and bravely questioned whether Congress really intended to rubberstamp life sentences onto people." See The Third Strike, https://www.thirdstrike campaign.com/powerless. Because Congress did not make this change retroactive, there are still people serving mandatory minimum life sentences under the law. See id. at https://www.thirdstrike campaign.com/policy.

94 This new ratio, like the old one, is suspect. See ACLU Submission on Racial Disparities in Sentencing, at 6 ("While the FSA was a step toward increased fairness, the 18-to-1 ratio continues to perpetuate the outdated and discredited assumptions about crack cocaine that gave rise to the 
The original sin of drug sentencing is the 1986 Act's reliance on drug type and quantity to identify "'major' and 'serious' dealers." 95 That framework has failed because drug type and quantity are often very bad proxies for culpability. ${ }^{96}$ In a 2011 report, the Commission wrote that "the quantity of drugs involved in an offense is not as closely related to the offender's function in the offense as perhaps Congress expected." ${ }^{\prime 97}$ More recently, the Commission observed that while Congress intended the 1986 Act's mandatory minimums to apply to high-level traffickers, they apply disproportionately to low-level offenders instead. ${ }^{98}$

The federal judiciary has likewise spoken out against mandatory minimum drug laws and their overemphasis on drug type and quantity. For example, in its 2013 letter to the Senate Judiciary Committee, the Judicial Conference outlined the problems with the law's misguided focus on drug type and quantity. ${ }^{99}$ Nonetheless, the First Step Act made no changes to that core organizing principle of the 1986 Act.

\section{B. The Sentencing Commission \& the Formulation of the Sentencing Guidelines}

With the exception of mandatory minimum sentencing statutes, for most of the 19th and 20th centuries, federal judges had near unlimited sentencing discretion. ${ }^{100}$ Around the same time that politicians like then-Congressman Bush were questioning the wisdom of mandatory minimum sentences, prominent judges and academics began to rail against the extent of judicial discretion and the perceived sentencing disparities that resulted. Judge Marvin Frankel, called the "father of sentencing

unwarranted 100-to-1 disparity in the first place.”); see also Alexander, supra note 88, at 139 (“There should be no disparity - the ratio should be one-to-one.").

95 Kimbrough, 552 U.S. at 95.

96 For example, the Commission's data shows that only $7.3 \%$ of people who were sentenced for drug offenses in Fiscal Year 2019 were considered to be "high-level" traffickers: leaders, managers, or supervisors in drug enterprises. 2019 ANNUAL REPORT, supra note 13, at 117, Table D-9. The FSA acknowledges that role in the offense distinguishes drug offenders from one another. It codifies that those who the sentencing judge determines to be an "organizer, leader, manager, or supervisor of others in the offense" are ineligible for "earned time credits" for participating in rehabilitative programming. See First Step Act of 2018, Pub. L. No. 115-391, § 756, 132 Stat. 5194, 5202 (2018).

97 U.S. Sentencing Comm'n, 2011 Report To The Congress: Mandatory Minimum Penalties In The Federal Criminal Justice System 350 (2011).

98 See 2017 Mandatory Minimum Report, supra note 28, at 6 (noting that "nearly one-third (32.2\%) of Couriers and more than one-quarter of Mules (25.4\%) were convicted of such offenses").

99 See, e.g., Letter from Honorable Robert Holmes Bell to Senator Patrick J. Leahy, at 5 (Sept. 17, 2013), https://www.uscourts.gov/sites/default/files/judge-bell-chairman-leahy-mandatory-minimu ms.pdf.

100 See, e.g., Mistretta v. United States, 488 U.S. 361, 363 (1989). 
reform," led the charge to cabin judges' sentencing discretion. ${ }^{101}$ He believed that limiting discretion would promote sentencing uniformity and drastically reduce disparities. ${ }^{102}$ While pre-guidelines sentencing disparities certainly existed, Judge Frankel "did not foresee (or at least did not discuss) the possibility that written sentencing rules could have the effect of transferring sentencing discretion [from judges] to prosecutors." "103

Judge Frankel's concerns about judicial discretion were heeded by those on Capitol Hill and culminated in the Sentencing Reform Act of 1984 ("SRA"). The SRA drastically changed federal judges' role in the sentencing process and curtailed their discretion. The centerpiece of the SRA was the creation of the Commission, which in turn authored the federal sentencing guidelines.

The Commission has several statutory purposes: (1) to establish "sentencing policies and practices" that satisfy the $\S 3553$ (a) purposes of sentencing, including avoiding unwarranted sentencing disparities, while at the same time providing "sufficient flexibility to permit individualized sentences when warranted by mitigating or aggravating factors" not accounted for by the guidelines; (2) to reflect "advancement in knowledge of human behavior as it relates to the criminal justice process"; and (3) to "develop means of measuring the degree to which the sentencing, penal, and correctional practices are effective in meeting the purposes of sentencing" in $\S 3553(\mathrm{a})(2) .{ }^{104}$

The SRA established safeguards to ensure that the Commission employed an empirical approach. It required the Commission to review and revise the guidelines based on consultation with all the players in the system, including judges and experts in the field. ${ }^{105}$ It also mandated collecting and systematizing data about the sentencing process, the sentences judges impose, and the relationship between those sentences and the $\S 3553$ (a) factors. ${ }^{106}$

As the Supreme Court observed in Rita, the Commission's reliance on empirical evidence and its review and revision of the guidelines over time in light of judicial decisions, sentencing data, and consultation with participants and experts are at the core of its characteristic institutional role. ${ }^{107}$ The Supreme Court saw this iterative process as essential: "The Commission's work is ongoing. The statutes and the Sentencing Guidelines themselves foresee a continuous evolution helped by the

101 Kate Stith, The Arc of the Pendulum: Judges, Prosecutors, and the Exercise of Discretion, 117 YALE L.J. 1420, 1427 (2008).

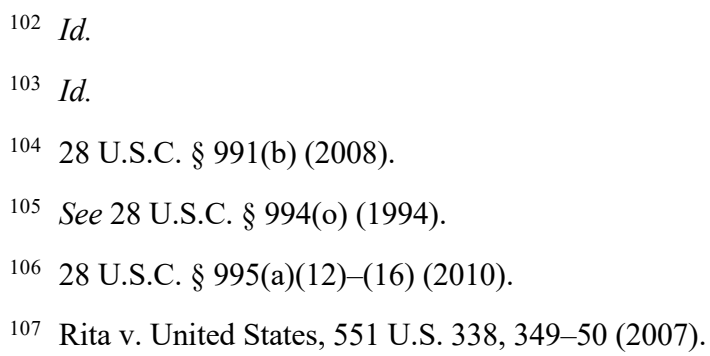


sentencing courts and courts of appeals in that process." 108 One crucial aspect of this process is that sentencing judges must articulate reasons for their sentences. ${ }^{109}$

Congress expected the Commission to take stock of data and past sentencing practices in formulating the guidelines, and anticipated that guideline sentences would be - on average - similar to pre-guidelines sentences in most cases. ${ }^{110}$ The Commission began with an "empirical examination of 10,000 presentence reports setting forth what judges had done in the past and then modifying and adjusting past practice[.]"111 From there, the Commission incorporated "a vast array of heavily weighted aggravating factors" $" 12$ and set its standard for when judges could sentence below the guidelines, permitting downward departures only in "atypical" cases. ${ }^{113}$ The Commission did not explain why it chose to undervalue mitigating factors in the guidelines. ${ }^{114}$ Moreover, it "did not estimate the impact of mitigating offender characteristics on past sentences," even though "judges had routinely considered those factors." 115 As a result, there are real questions about whether the Commission's formulation of the guidelines was based on empirical evidence and past practices, as Congress directed. ${ }^{116}$

The guidelines are a complex and rigid set of sentencing factors based on the seriousness of the offense and the person's criminal history. Each federal crime is assigned a base offense level, which is the starting point for determining the seriousness of the particular offense. ${ }^{117}$ In addition to the base offense levels, each offense has specific offense characteristics that increase or decrease the base offense level. There are also adjustments and departures, which similarly increase or decrease the base offense level. The result of these calculations is the total offense level. That is coupled with the person's criminal history category-ranging from one to six based on prior criminal history - to produce a guidelines range in months. There are also recidivist sentencing provisions, like the career offender guideline,

108 Id. at 350.

109 Id.

110 S. REP. No. 98-225, at 116 (1983).

111 Rita, 551 U.S. at 349.

112 Amy Baron-Evans \& Thomas W. Hillier II, The Commission's Legislative Agenda to Restore Mandatory Guidelines, 25 FED. SENT'G REP. 293, 294 (2013).

$113 I d$.

$114 I d$.

$115 I d$.

116 See, e.g., id.

117 U.S. Sentencing Comm'n, An Overview of the Federal Sentencing Guidelines, http://www.ussc.gov/sites/default/files/pdf/about/overview/Overview_Federal_Sentencing_Guideline s.pdf. 
which override offense-specific guidelines and set the offense level based on the offense's maximum penalty. ${ }^{118}$ The guidelines undervalue mitigating factors and give them little role at sentencing. ${ }^{119}$

Congress requires judges to communicate regularly with the Commission about the sentences they impose. Pursuant to 28 U.S.C. § 994(w), the Chief Judge of every federal district must submit to the Commission, within thirty days following the entry of judgment, a report of the sentence. ${ }^{120}$ The report must include "the written statement of reasons for the sentence imposed (which shall include the reason for any departure from the otherwise applicable guideline range .... )." ${ }^{121}$ Judges may also, of course, issue written opinions that explain their decisions.

\section{The Booker "Revolution" and Kimbrough}

Before United States v. Booker rendered the guidelines advisory, it was virtually mandatory for judges to sentence people within the applicable guideline range. If the sentencing judge misapplied the guidelines or departed from the range for any reason beyond those allowed for by the guidelines, appellate judges were on hand to "police" them. ${ }^{122}$ With looming appellate review, the Commission's "proclamations were not merely 'guidelines' or recommendations, but enforceable rules that sentencing judges were legally obliged to follow." 123 In essence, the Commission "micromanage[d] the sentencing function of federal [sentencing] judges," And the courts of appeals did the same. ${ }^{124}$

Judges frequently expressed their displeasure at the rigidity of the guidelines, in ways similar to their frustration with mandatory minimums. An article in the Baltimore Sun in 1992 - just five years after the guidelines went into effect — put it

118 U.S. Sentencing Guidelines Manual § 4B1.1 (U.S. Sentencing Comm’n 2018).

119 See, e.g., Carissa Byrne Hessick, Why Are Only Bad Acts Good Sentencing Factors?, 88 B.U. L. REV. 1109, 1119 (2008) ("Prior to the enactment of the Federal Sentencing Guidelines, a defendant's prior good works were often raised and considered at sentencing. When it initially formed and directed the U.S. Sentencing Commission to develop the Guidelines, Congress made no specific mention of an offender's prior good works as a sentencing factor.").

12028 U.S.C. $\S 992(\mathrm{w})(1) \&(\mathrm{w})(1)(B)(2018)$.

121 Id.

122 See Kate Stith, The Hegemony of the Sentencing Commission, 9 FED. SENT'G REP. 14, 16 (1996) (noting the responsibility of courts of appeals to "police" departures); Alison Siegler, Rebellion: The Courts of Appeals' Latest Anti-Booker Backlash, 82 U. CHI. L. REv. 201, 202 (2015) ("From 1987 to 2005 , ... the Guidelines were mandatory and appellate courts policed sentencing courts closely, engaging in rigorous, guidelines-centric appellate review.") (internal quotation marks and citations omitted).

123 Stith, supra note 101, at 1429.

124 Margareth Etienne, Remorse, Responsibility, and Regulating Advocacy: Making Defendants Pay for the Sins of Their Lawyers, 78 N.Y.U. L. REV. 2103, 2122 (2003). 
this way: "Judges say the guidelines fail to achieve fairness, often are too confusing and undermine the fairness of criminal trials by taking power from the judge, the impartial player, and handing it to the prosecutors, who are advocates for the government." 125 These critiques have continued over the years. In 2016, District Court Judge John Coughenour, who became a judge before the advent of the guidelines regime, opined that "the standardization of sentences has resulted in less justice, not more, and that the way the nation sentences criminals today has created greater inequality, not less." 126

While federal public defenders and other criminal defense attorneys challenged the guidelines as unconstitutional from their inception, the guidelines were widely seen as unassailable, even into the early 2000s. Then the Supreme Court decided United States v. Booker. The facts of the case were simple: Booker was arrested and police officers found 92.5 grams of crack cocaine in his duffel bag. ${ }^{127} \mathrm{He}$ later admitted to selling an additional 566 grams of crack cocaine. ${ }^{128}$ He went to trial and the jury found that he was guilty of possessing with intent to distribute at least 50 grams of crack. ${ }^{129}$ At sentencing, however, the district court judge found by a preponderance of the evidence that he had distributed more crack than the jury had found. ${ }^{130}$ Accordingly, the judge increased Booker's base offense under the guidelines and sentenced him to thirty years. ${ }^{131}$

Booker appealed, arguing that his sentence violated the Sixth Amendment. The Supreme Court ultimately issued two holdings: (1) the constitutional holding - that the guidelines violated the Sixth Amendment because they allowed judges to find facts that increased the defendant's punishment above the statutory maximum by a preponderance of the evidence rather than the jury making those findings beyond a reasonable doubt; and (2) the remedial holding - that the constitutional infirmity could be remedied by making the guidelines advisory, as opposed to mandatory. ${ }^{132}$

In Kimbrough v. United States, the Supreme Court extended judicial discretion still further, holding that district court judges could vary from the guidelines based

125 Norris P. West, Federal Judges Complain of Rigid Sentencing Guidelines, BALTIMORE SUN (Sept. 28, 1992), https://www.baltimoresun.com/news/bs-xpm-1992-09-28-1992272170-story.html.

126 Matthew Van Meter, One Judge Makes the Case for Judgment, The ATLAnTiC (Feb. 25, 2016), https:/www.theatlantic.com/politics/archive/2016/02/one-judge-makes-the-case-for-judgment/ 463380/.

127 United States v. Booker, 543 U.S. 220, 227 (2005).

128 Id. at 235.

129 Id. at 227.

130 Id.

131 Id.

132 Id. at $244-45$. 
on a policy disagreement. ${ }^{133}$ Kimbrough is in many ways a surprising case, both because of its procedural history and its holding. There was no circuit split—instead, the appellate courts had uniformly held that judges could not disagree with the crack/powder cocaine guidelines on policy grounds. The Supreme Court accepted the case nonetheless and ultimately granted sentencing judges more power. ${ }^{134}$

The district court judge in Kimbrough had concluded that the 100-to-1 crack/powder disparity led to a sentencing range that was much greater than necessary to accomplish $\S 3553$ (a)'s objectives. ${ }^{135}$ He contrasted Kimbrough's guidelines range of 228 to 270 months (19 to 22 years) with the drastically lower 97 to 106 month range ( 8 to 9 years) that Kimbrough would have faced if the drug were powder cocaine, rather than crack cocaine. ${ }^{136} \mathrm{He}$ found this difference "unbelievable" and "clearly inappropriate." ${ }^{137}$ Accordingly, the judge varied below the applicable guideline range, although he could not reduce Kimbrough's sentence below the 15-year mandatory minimum, which he also believed was "too long." 138 The government appealed the sentence and, in a per curiam opinion, the Fourth Circuit vacated the sentence as unreasonable. ${ }^{139}$

The Supreme Court began its opinion by laying out the history of the crack/powder disparity, starting with the 1986 Act's focus on drug quantity to set mandatory minimum sentences. ${ }^{140}$ As the Court explained, the 100-to-1 ratio was created because "Congress apparently believed that crack was significantly more dangerous than powder cocaine." ${ }^{141}$ But in reaching this conclusion, Congress relied on "assumptions," not evidence. ${ }^{142}$ In lockstep response, the Commission developed guidelines that simply adopted Congress' weight-driven scheme without basing the drug guidelines "on data about past sentencing practices" as it was supposed to do. ${ }^{143}$ Accordingly, the Supreme Court concluded that the Commission "did not use [its] empirical approach in developing the Guidelines sentences for drug-trafficking

133 Kimbrough v. United States, 552 U.S. 85 (2007). A "variance" is a sentencing reduction or increase that is imposed pursuant to $\S 3553$ (a). See Irizarry v. United States, 553 U.S. 708, 714-15 (2008).

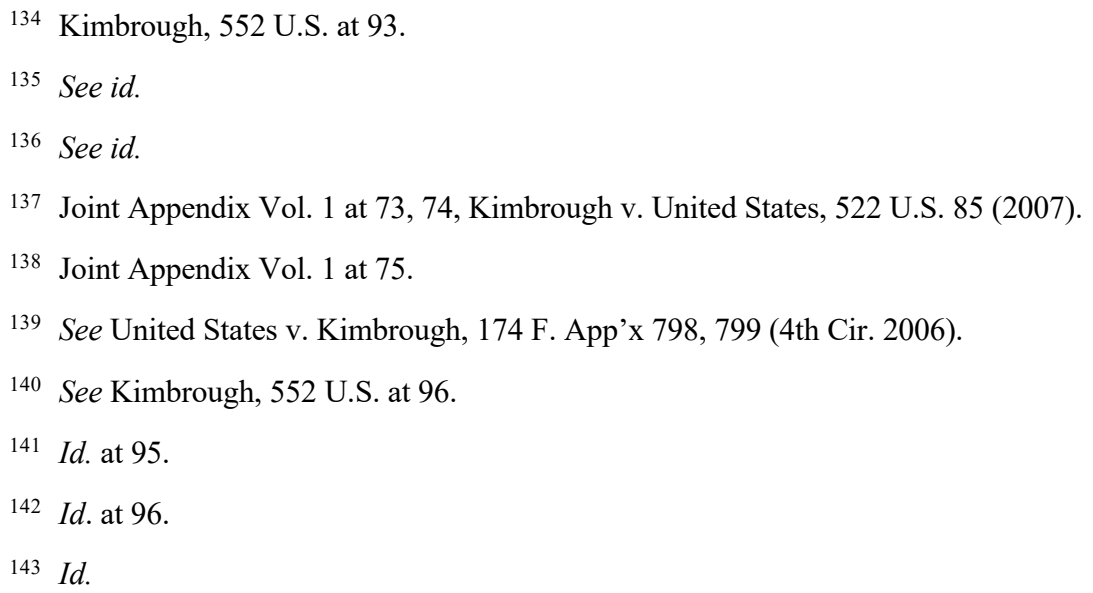


offenses." 144 This failure on the Commission's part diminished the reliability of the resulting guidelines, which in turn increased judges' authority to deviate from them. Because the drug guidelines did not "exemplify the Commission's exercise of its characteristic institutional role," judges were permitted to vary from them, even in a "mine-run" case. ${ }^{145}$

The Supreme Court sent an important message in Kimbrough: Congress' failure to enact evidence-based reform authorized district court judges to ignore the crack/powder disparity and to make discretionary sentencing decisions in individual cases. The Court exhaustively detailed Congress' intransigence in the face of the Commission's decades-long efforts to eliminate or reduce the disparity. In 1995, the Commission recommended a 1:1 ratio to Congress, but Congress rejected it. ${ }^{146}$ The Commission continued to urge Congress to reduce the disparity in the years that followed. ${ }^{147}$ In a 2002 report to Congress, the Commission explained why the disparity was so problematic, and emphasized that the disparity "fails to meet the sentencing objectives set forth by Congress in both the Sentencing Reform Act and the 1986 Act." 148 Finally, in 2007, the Commission took action on its own, reducing the base offense level for crack cocaine by two levels, while acknowledging that a "comprehensive solution" required Congressional action. ${ }^{149}$

Although Kimbrough clearly expanded judicial sentencing discretion, it left important questions unanswered. One was whether judges could vary from the guidelines based on a "policy disagreement with them, and not simply based on an individualized determination that they yield an excessive sentence in a particular case." ${ }^{.150}$ In Spears v. United States, the Supreme Court answered this question in the affirmative, confirming that individual judges could substitute their own ratio to correct the crack/powder disparity. ${ }^{151}$

Another post-Kimbrough question was whether a judge could disagree on policy grounds with a guideline that was the product of a congressional directive, such as the career offender guideline or fast-track guideline. Most circuits

144 Id. at 96.

145 See Kimbrough, 552 U.S. at 109-10.

146 See id. at 99.

147 See id. at 99-100.

148 Id. at 97 (citing U.S. SENTENCING COMM'N, REPORT to CONGRESS: CoCAINE AND FEDERAL Sentencing Policy (2002)).

149 Id. at 100 (citing U.S. Sentencing Comm'N, Report to Congress: CocAine ANd Federal Sentencing Policy (2007)).

150 Spears v. United States, 555 U.S. 261, 264 (2009).

151 Id. at 265. The judge in Spears determined that the proper ratio for crack/powder is 20-to-1. See id. at 266. 
determined that sentencing judges had the discretion to do so. ${ }^{152}$ But in the career offender context, the Eleventh Circuit and the Seventh Circuit disagreed. The Eleventh Circuit reasoned that the Supreme Court had drawn an explicit distinction between the way the guidelines treated crack and powder cocaine-which Congress did not direct - and the guidelines' harsh punishment of career offenders - which Congress expressly directed. ${ }^{153}$ The Seventh Circuit agreed in United States $v$. Welton. ${ }^{154}$ On petition for a writ of certiorari, the Solicitor General confessed error, concluding that the Eleventh Circuit's holding was inconsistent with Booker and Kimbrough. ${ }^{155}$ The Solicitor General recommended that the court grant the petition, vacate the Eleventh Circuit's judgment, and remand for further proceedings, which the Supreme Court did. Accordingly, it is now settled law that district judges can categorically disagree on policy grounds with the career offender guideline - or any other guideline that is the product of a congressional directive.

\section{EFFORTS TO REFORM FEDERAL DRUG LAWS}

\section{A. The Problem of High Pretrial Detention Rates in Drug Cases}

Just as the drug statutes and guidelines have contributed to high sentences at the back end, the BRA's provisions that favor detention in drug cases have driven high federal pretrial detention rates at the front end. ${ }^{156}$ In 2017, the Administrative Office of the U.S. Courts published the first study to examine the effect of the presumptions of detention on pretrial detention rates since the BRA's passage. ${ }^{157}$ That AO study found that, from 1995 to 2010, the percentage of people charged with drug offenses who were detained pretrial increased from $76 \%$ to $84 \% .{ }^{158}$ Moreover, the AO study shows that the presumption of detention has become "an almost de

152 See Tom McKay, Judicial Discretion to Consider Sentencing Disparities Created by FastTrack Programs: Resolving the Post-Kimbrough Circuit Split, 48 AM. CRIM. L. REV. 1423, 1445 (2011) (outlining the career offender circuit split); Alison Siegler, Disparities and Discretion in Fast-Track Sentencing, 21 FED. SENT'G REP. 299, 300 (2009) (describing the fast-track circuit split).

153 United States v. Vazquez, 558 F.3d 1224, 1228 (11th Cir. 2009).

154583 F.3d 494, 499 (7th Cir. 2009).

155 See Brief for the United States at 10, Vazquez v. United States, 558 U.S. 1144 (2010) (No. 09-5370).

156 See Austin, supra note 17, at 52 ("Since 1984, the pretrial detention rate for federal defendants has been steadily increasing. Recent work has aimed to address why the detention rate continues to rise and if there may be alternatives that could slow or reverse this trend. The presumption for detention statute, which assumes that defendants charged with certain offenses should be detained, has been identified as one potential factor contributing to the rising detention rate."); see also Siegler Written Statement, supra note 15, at 13, 16.

157 See Austin, supra note 17, at 53.

$158 I d$. 
facto detention order in almost half of all federal cases" and "has contributed to a massive increase in the federal pretrial detention rate, with all of the social and economic costs associated with high rates of incarceration."

This is far from what the BRA intended. Congress enacted the presumption of detention to "detain high-risk defendants who were likely to pose a significant risk of danger to the community" 160 and "major drug traffickers" who were likely to flee if released. ${ }^{161}$ The AO study found that the presumption has strayed from "its intended purpose" of "detaining high-risk" individuals who are "likely to pose a significant danger to the community," and instead over-incarcerates low-risk defendants. ${ }^{162}$ For example, when a low-risk individual is not facing a presumption of detention, they are released $94 \%$ of the time. ${ }^{163}$ Yet an identically low-risk individual in a presumption case is released just $68 \%$ of the time. ${ }^{164}$ All in all, the drug presumption is a "poorly defined attempt to identify high-risk defendants based primarily on their charge." 165

The AO study led the Judicial Conference to ask Congress to eliminate the presumption in most drug cases because it was "unnecessarily increasing detention rates of low-risk defendants." 166 Specifically, the Judicial Conference recommended that Congress limit the drug presumption to people with very serious criminal records. ${ }^{167}$ In reiterating this recommendation in 2020, the Judicial Conference explained: "This provision reduces unnecessary pretrial detention of certain low-risk defendants charged with drug trafficking offenses by limiting the application of the presumption of detention to defendants whose criminal history suggests that they pose a higher risk of failing to appear... or that they may be a danger to the community." 168 This recommendation implies that the federal judiciary's policymaking body does not believe that all individuals subject to the presumption automatically pose a danger to the community. Yet Congress has taken no action on

159 Id. at 61.

${ }^{160} I d$. at $56-57$.

161 See supra Part I (discussing the legislative history of the drug presumption).

162 See Austin, supra note 17, at 56-57; see also Matthew G. Rowland, The Rising Federal Pretrial Detention Rate in Context, 82 Fed. Probation 13, 18 (2018).

163 Siegler Written Statement, supra note 15, at 14 (citing Austin, supra note 17, at 57).

$164 I d$.

165 Austin, supra note 17, at 60.

166 JUdiCIAL CONFERENCE REPORT, supra note 7, at 10.

167 See id. (recommending that the presumption apply only to people who "have previously been convicted of two or more offenses described in subsection [3142](f)(1)," which are limited to drug, gun, terrorism, minor victim, and certain violent offenses).

168 See 2020 Judicial Conference Letter, supra note 8, at Enclosure 2 at 2. 
either recommendation, and the drug presumption of detention continues to apply to most federal drug cases around the country.

As the Judicial Conference has recognized, high detention rates come with significant costs. ${ }^{169}$ While one of the BRA's rationales for pretrial detention is the protection of the community, evidence shows that detention is more likely to increase crime than prevent it. A 2017 study found that although pretrial detention reduces a person's criminal activity in the short term, "by eighteen months posthearing, detention is associated with a $30 \%$ increase in new felony charges and a $20 \%$ increase in new misdemeanor charges," which is consistent with other research that "even short-term detention has criminogenic effects." ${ }^{170}$ Moreover, data shows that pretrial detention - even for a few days - is correlated with higher rates of recidivism. ${ }^{171}$ This finding is especially concerning as people are spending a longer time in jail awaiting trial. ${ }^{172}$

Evidence from the state and federal systems demonstrates that pretrial detention hurts people and communities in other ways as well. People who are detained are more likely to "lose their jobs, their homes, their health, and even their children" than those who are released. ${ }^{173}$ On the job front, a recent study found that people who were released on bail had much better employment outcomes in the formal employment market. ${ }^{174}$ People who are detained are less likely to find a job or have any income, and have lower incomes if they are employed. ${ }^{175}$ Pretrial detention also contributes to housing instability and homelessness. A Federal Probation study found that of those detained less than three days, $29.9 \%$ reported that their housing situation became less stable; the number rose to $37.2 \%$ for those detained more than three days. ${ }^{176}$

169 See id.

170 Paul Heaton et al., The Downstream Consequences of Misdemeanor Pretrial Detention, 69 Stan. L. REv. 711, 718 (2017); see also Arpit Gupta, et al., The Heavy Costs of High Bail: Evidence from Judge Randomization, 45 J. LEGAL STUD. 471 (2016).

171 See Christopher L. Lowenkamp et al., The Hidden Costs of Pretrial Detention, The ARNOLD FOUNDATION 19 (2013). In the study, people who were detained were 1.3 times more likely to recidivate compared to people released on bail at some point before trial. Id.

172 Austin, supra note 17, at 53-54 ("As of 2016, the average period of pretrial detention for a pretrial defendant had reached 255 days, although several districts average over 400 days in pretrial detention.").

173 Alison Siegler \& Erica Zunkel, Rethinking Federal Bail Advocacy to Change the Culture of Detention, The CHAmPION, at 5 (July 2020), https://ssrn.com/abstract=3601230 [hereinafter Rethinking Federal Bail Advocacy].

174 See Will Dobbie et al., The Effects of Pretrial Detention on Conviction, Future Crime, and Employment: Evidence from Randomly Assigned Judges, 108 AM. ECON. REV. 201, 227 (2018).

175 See id.

176 Alexander M. Holsinger \& Kristi Holsinger, Analyzing Bond Supervision Survey Data: The Effects of Pretrial Detention on Self-Reported Outcomes, 82 FED. Probation 39, 42 (2018). 
Finally, pretrial detention contributes to worse case outcomes. A detained person may feel pressure to "plead guilty to get out of jail, or accept an overly punitive plea deal because detention impaired her ability to gather evidence or meet with her lawyer. She may be less motivated to fight the charges when the fixed costs of incarceration have already been paid: stigma, loss of employment, housing or child care, etc." 177 Research also shows that in the federal system, pretrial detention "significantly increases sentences, decreases the probability that a defendant will receive a below-Guidelines sentence, and decreases the probability that they will avoid a mandatory minimum if facing one." 178

These sweeping collateral consequences are particularly problematic in light of data that people in the federal system are extremely unlikely to commit new crimes on bond or fail to appear in court. ${ }^{179}$ As we have highlighted elsewhere, over $98 \%$ of people released in federal cases do not commit new crimes on release, and $99 \%$ appear for court. ${ }^{180}$ This data proves that "when release increases, crime and flight do not," 181 strongly suggesting that judges should do as we propose and safely release more people on bail.

\section{B. Federal Drug Laws}

Federal judges are particularly well situated to drive drug law reform because they have long been vocal about the problems with federal drug laws, in particular mandatory minimums and statutory recidivist enhancements. It is hard to think of a topic about which federal judges have been more outspoken-from Supreme Court justices to district court judges. In calling on federal judges to speak out against mass incarceration, Judge Jed Rakoff observed: "On one issue - opposition to mandatory minimum laws - the federal judiciary has been consistent in its opposition and clear in its message." 182 In 2016, Supreme Court Justice Stephen Breyer went before the House of Representatives' Appropriations Subcommittee and lambasted mandatory minimums: "You want mandatory minimums? I've said publicly many times that I

177 Megan Stevenson, Distortion of Justice: How the Inability to Pay Bail Affects Case Outcomes, J.L. ECON. \& ORG. 511, 512 (2018) (finding that pretrial detention leads to a 13\% increase "in the likelihood of being convicted on at least one charge.").

178 Stephanie Holmes Didwania, The Immediate Consequences of Pretrial Detention, 30 AM. L. ECON. REV. (forthcoming 2020); see also Austin, supra note 17, at 53-54 (citing studies that show worse case outcomes when people are detained pretrial).

179 See Siegler Written Statement, supra note 15, at 4.

180 See Siegler \& Zunkel, Rethinking Federal Bail Advocacy, supra note 173, at 3 (demonstrating that "this near-perfect compliance rate is seen equally in federal districts with very high release rates and those with very low release rates"); ADMIN. OfF. U.S. CTS., Judicial Business: Federal Pretrial Services Tables, Table H-15 (2019), https://perma.cc/LYG4-AX4H.

181 Siegler \& Zunkel, Rethinking Federal Bail Advocacy, supra note 173, at 3-4.

182 Rakoff, supra note 29. 
think they're a terrible idea." ${ }^{\prime 183}$ Retired Justice Anthony Kennedy told the American Bar Association in 2003: "I can accept neither the necessity nor the wisdom of federal mandatory minimums. In too many cases, mandatory minimum sentences are unwise and unjust."184

Federal judges have assailed drug mandatory minimums in a variety of ways. Mandatory minimums "distort the sentencing process and mandate unjust sentences." ${ }^{185}$ They discourage people from exercising their constitutional right to trial. ${ }^{186}$ They were created to punish high-level drug traffickers, but often do not. ${ }^{187}$ The most culpable receive more lenient sentences because they can provide "substantial assistance" to the government, while the least culpable have little, if any, information of value. ${ }^{188}$ They disparately impact people of color. ${ }^{189}$ They take sentencing discretion from judges and give it to prosecutors. ${ }^{190}$ These critiques have come from judges with wide-ranging judicial philosophies. For example, in United States v. Brigham, Seventh Circuit Judge Frank Easterbrook acknowledged the "troubling" nature of drug mandatory minimums that punish the least culpable most severely because "it accords with no one's theory of appropriate punishments."191

183 Justices Anthony Kennedy \& Stephen Breyer, Supreme Court Fiscal Year 2016 Budget (CSPAN User Created Clip Mar. 23, 2015), https:/www.c-span.org/video/?c4532246/user-clip-justiceskennedy-breyer-criminal-justice.

184 Justice Anthony Kennedy, Speech at the American Bar Association Annual Meeting: An Address by Anthony M. Kennedy (Aug. 9, 2003), https://www.supremecourt.gov/publicinfo /speeches/sp_08-09-03.html.

185 United States v. Dossie, 851 F. Supp. 2d 478, 478 (E.D.N.Y. 2012).

186 United States v. Bowen, 2012 U.S. Dist. LEXIS 50670 (E.D. La. 2012) (“The problem with mandatory minimums is that they have a coercive effect ... . This extraordinary pressure can result in false cooperation and guilty pleas by innocent people.”).

187 See, e.g., United States v. Leitch, 2013 WL 753445, at *2 (E.D.N.Y. 2013) (““[M]any lowlevel drug trafficking defendants are receiving the harsh mandatory minimums that Congress explicitly created only for leaders and managers of drug operations.").

188 See, e.g., Dossie, 851 F. Supp. 2d at 487.

189 See, e.g., United States v. Clary, 846 F. Supp. 768, 772, 792 (E.D. Miss. 1994) (“'[T]he ‘100 to 1 ' ratio, coupled with mandatory minimum sentencing provided by federal statute has created a situation that reeks with inhumanity and injustice. .. . [I]f young white males were being incarcerated at the same rate as young black males, the statute would have been amended long ago.").

190 See, e.g., Dossie, 851 F. Supp. 2d at 485 ("The government simply dictated a five-year sentence without even having to allege, let alone prove, the aggravating fact that it implied warranted the sentence.").

191977 F.2d 317, 318 (7th Cir. 1992); see also Opinion: Justice Kennedy Speaks Out, N.Y. Times (Aug. 12, 2003), https://www.nytimes.com/2003/08/12/opinion/justice-kennedy-speaksout.html ('Justice Kennedy said he could accept neither their 'necessity' nor their 'wisdom.' He is hardly alone, even among conservative[] [judges], in raising these objections."). 
In 2010, federal judges were surveyed about their views on drug mandatory minimum sentences and the results were overwhelmingly negative. Seventy-six percent responded that the crack cocaine mandatory minimum was too high; $54 \%$ responded that the marijuana mandatory minimum was too high; and approximately $44 \%$ responded that the heroin, drug, and powder cocaine mandatory minimums were too high. ${ }^{192}$ By contrast, a majority of them responded that the mandatory minimums for firearms and child pornography production and distribution offenses were "appropriate." 193

The Judicial Conference of the United States has long opposed mandatory minimums and supported legislative reform. ${ }^{194}$ In a 2013 letter to Congress, the Judicial Conference's Criminal Law Committee stated: "For 60 years, the Judicial Conference has consistently and vigorously opposed mandatory minimum sentences" because they waste taxpayer dollars, produce "disproportionately severe sentences," and "undermine confidence in the judicial system." 195 The letter highlighted drug mandatory minimums in particular as unfair because "the only considerations" are the type and amount of drugs. ${ }^{196}$

Federal judges have also criticized recidivist drug enhancements that until 2018 could increase mandatory minimums up to life imprisonment. (The FSA reduced and narrowed these recidivist enhancements, but left them on the books.) Retired District Court Judge John Gleeson observed that recidivist enhancements "coerce[] guilty pleas and produce[] sentences so excessively severe they take your breath away." 197 First Circuit Judge Gilbert Merritt condemned a prosecutor's decision to double the 10-year mandatory minimum to 20 years in the case of a mentally-ill man whose offense was nonviolent, saying it "passe[d] all understanding." ${ }^{198}$ Judge Merritt also highlighted Congress' dysfunction on the drug law reform front in the face of sustained criticism: "[ $\mathrm{t}]$ he Judicial Conference of the United States for almost 20 years, and the Sentencing Commission for almost 10 years, have pleaded with

192 U.S. Sentencing Comm’n, Results of Survey of United States District Judges JANUARY 2010 Through MARCH 2010 (June 2010), https://www.ussc.gov/sites/default/files/pdf/ research-and-publications/research-projects-and-surveys/surveys/20100608_Judge_Survey.pdf.

193 Id.

194 See, e.g., Letter from Honorable Robert Holmes Bell to Senator Patrick J. Leahy, at 1 (Sept. 17, 2013), https://www.uscourts.gov/sites/default/files/judge-bell-chairman-leahy-mandatory-minim ums.pdf.

195 Id. at $1-2,4$.

196 Id. at 5.

197 United States v. Kupa, 976 F. Supp. 2d 417, 420, 459 (E.D.N.Y. 2013) (“"The prior felony [ $\S 851]$ information ushered that 800-pound gorilla into the case at the eleventh hour and it took the case over. Once it was filed, everything that followed was done with all eyes on the draconian sentence that a jury's verdict of guilty would require me to impose.").

198 United States v. Gonzalez-Ramirez, 561 F.3d 22, 31 (1st Cir. 2009) (Merritt, J., concurring). 
the judiciary committees of Congress to do something about the serious injustices that these long mandatory minimum sentences impose - to no avail." 199

Beyond the federal judiciary, there is widespread agreement that federal mandatory minimum drug laws are inhumane, waste taxpayer money, and deprive judges of sentencing discretion. In a study done for the Pew Charitable Trusts, voters were asked their views about people who violate drug laws. Told that a large percentage of the people in federal prison are incarcerated for drug offenses, sixtyone percent said, "[t]hat is too many drug criminals taking up too much space in our federal prison system. More of that space should be used for people who have committed acts of violence or terrorism."200 The same study found that eight in ten voters support giving judges the flexibility to determine drug sentences based on the individualized facts of a case. ${ }^{201}$

Despite the judiciary's vocal opposition and public censure, Congress has not meaningfully reformed mandatory minimum drug laws since they were enacted nearly thirty years ago. ${ }^{202}$ The FSA tinkers around the edges of reform, but does not alter the 1986 Act's original sin of pegging drug sentences to drug type and quantity, nor does it eliminate drug mandatory minimums. ${ }^{203}$ On the positive side, the FSA reduces and narrows harsh mandatory minimum recidivist enhancements, ${ }^{204}$ expands the safety valve so that more people are eligible to receive a sentence below the mandatory minimum if they meet certain (still stringent) requirements, ${ }^{205}$ and makes the Fair Sentencing Act of 2010 retroactive.

199 Id.

200 Mellman Group \& Public Opinion Strategies, National Survey Key Findings-Federal Sentencing \& Prisons, Pew Trusts, 1 (Feb. 10, 2016).

201 Id.

202 While it is beyond the scope of this article, the Department of Justice remains a consistent roadblock to drug law reform. See generally Rachel E. Barkow \& Marc Osler, Designed to Fail: The President's Deference to the Department of Justice in Advancing Criminal Justice Reform, 59 WM. \& MARY L. REV. 387, 418, 421 (2017) (describing the Department of Justice's "institutional biases in favor of the statute quo and avoiding any risk that someone released early might commit a dangerous offense" and its resistance to mandatory minimum reform because such penalties provide leverage to secure pleas and cooperation).

203 First Step Act of 2018, Pub. L. No. 115-391, § 756, 132 Stat. 5194, 5202 (2018).

204 The FSA made two changes. First, it changed the length of the enhancement. Previously, 21 U.S.C. $\S \S 841$ and 960 permitted prosecutors to seek a 20 -year mandatory minimum if the person had one prior conviction for a "felony drug offense" (including simple possession) and a mandatory minimum of life if the person had two of those convictions, no matter how old. The new mandatory minimums are reduced to 15 years and 25 years respectively. Second, the FSA changed the definition of what type of offense qualifies for an increased mandatory minimum sentence. Now, only prior convictions for a "serious drug felony" or a "serious violent felony" count. See First Step Act of 2018, Pub. L. No. 115-391, § 756, 132 Stat. 5194, 5202 (2018).

205 Prosecutors have an important say in who receives safety valve relief. The guidelines provide that a person must "truthfully provide[] to the Government all information and evidence the defendant has concerning the offense or offenses that were part of the same course of conduct or of a common 
Certainly, the FSA has ameliorated problems at the margins and is better than nothing. Moreover, reformers have talked earnestly about the FSA being just thata "first step" - with plans to push additional reform. ${ }^{206}$ Yet, the politics of federal criminal justice reform remain complicated. Senator Tom Cotton (R-AK) was a vocal critic of the First Step Act and nearly succeeded in defeating the bill. While lobbying against it, he called for increasing drug sentences. ${ }^{207}$ Senator Cotton also slammed prior iterations of federal criminal reform, calling them "criminal leniency" bills. ${ }^{208} \mathrm{He}$ is sure to be a critic of any future bills. Senator John Kennedy (R-LA) issued a statement explaining why he opposed the FSA: "[T] important goal of the criminal justice system for American families is justice. This bill is backwards. It favors criminals over victims. It forgets that the ultimate goal is justice. We've seen what's happened with so-called criminal justice reform in Louisiana. People are literally getting killed." ${ }^{209}$ Even conservatives condemned Senator Kennedy's opposition to the FSA as "all wrong." 210

Senator Cotton and Senator Kennedy's comments are not surprising. National politicians traditionally have benefitted from being tough on crime and stoking fears about easing criminal laws, no matter how misguided those laws are. ${ }^{211}$ Senator Ted Cruz (R-TX) is a recent example. In 2015, he "criticized 'draconian mandatory minimum sentences' and bragged about supporting [the] bill that would cut them in

scheme or plan.” U.S. SEnTENCING Guidelines Manual $§$ 5C1.2(a)(5) (U.S. Sentencing Comm’N 2018). The safety valve guideline squarely permits a prosecutor to withhold a recommendation for relief - and, as a result, a sentence below the mandatory minimum - if she determines that the person has not been truthful. See id.; see also United States v. Montes, 381 F.3d 631, 634 (7th Cir. 2004) (discussing the truthful disclosure prong).

206 Ames Grawert \& Tim Lau, How the First Step Act Became Law-And What Happens Next, BRENNAN CENTER FOR JUSTICE (Jan. 4, 2019), https://www.brennancenter.org/our-work/analysisopinion/how-first-step-act-became-law-and-what-happens-next.

207 Tom Cotton, Lame-duck Congress' Rush for Criminal Justice Reform Plan Will Hurt, Not Help, USA TODAY (Nov. 15, 2018), https://www.usatoday.com/story/opinion/2018/11/15/tom-cottoncongresss-criminal-justice-reform-bill-opioids-laws-column/2003829002/.

208 Nick Gass, Sen. Tom Cotton: U.S. Has 'Under-Incarceration Problem,' Politico (May 19, 2016), https://www.politico.com/story/2016/05/tom-cotton-under-incarceration-223371.

209 Press Release, Sen. John Kennedy (R-La.) Stands Against So-called Criminal Justice Legislation (Dec. 18, 2018), https://www.kennedy.senate.gov/public/press-releases?ID=53A5A24BF362-4E78-978A-191F7C172F64.

210 Derek Cohen, Opinion: Tucker Carlson and John Kennedy Get the First Step All Wrong, WASH. EXAMINER (July 24, 2019), https://www.washingtonexaminer.com/opinion/tucker-carlson-andjohn-kennedy-get-the-first-step-act-all-wrong.

211 See Rachel Elise Barkow, Prisoners of Politics 110-12 (2019). 
half for federal drug offenders." ${ }^{212}$ His tune changed considerably after he launched his 2016 presidential bid. He became one of most vocal critics of the Sentencing Reform and Corrections Act, which was a precursor bill to the FSA. ${ }^{213}$ This type of politics is not just the province of Republicans. "Everybody in politics exploits race and crime, Democrats as much as Republicans, including, of course, Bill Clintonwho took time off his campaign for president to go back to Arkansas to preside over the execution of a mentally defective black prisoner." 214

The year 2020 may hold promise for criminal reform more generally. In the wake of George Floyd's death and nationwide protests calling for systemic change, federal politicians have introduced bills to reform policing ${ }^{215}$ and a bipartisan bill that makes modest reforms to releasing elderly and sick people from prison. ${ }^{216}$ They would be wise to focus on drug law reform. The continued use of federal mandatory minimum drug laws diminishes respect for the system and its players, including law enforcement. ${ }^{217}$

\section{THE PATH FORWARD: A MORE VOCAL JUDICIARY}

As of 2020, the federal criminal law reform landscape remains challenging, and the system continues to single out drug offenses for harsh treatment at the bail and sentencing stages.

212 Jacob Sullum, Ted Cruz Abandons Criminal Justice Reform on His Way to the White House, ForbeS (Jan. 28, 2016), https://www.forbes.com/sites/jacobsullum/2016/01/28/ted-cruz-abandonscriminal-justice-reform-on-his-way-to-the-white-house/\#3923b8e3548f.

$213 I d$.

214 Samuel G. Gross, Crime, Politics, and Race, 20 Harv. J.L. \& Pub. Pol'y 405, 412 (1997). See also ALEXANDER, supra note 88, at 56 ("[I]n 1992, presidential candidate Bill Clinton vowed that he would never permit any Republican to be perceived as tougher on crime than he.").

215 Sarah Ferris, et al., House Passes Sweeping Police Reform Bill, Politico (June 25, 2020), https://www.politico.com/news/2020/06/25/police-reform-plan-house-339691.

216 Press Release, Durbin, Grassley Introduce New Bipartisan Legislation To Reform Elderly Home Detention And Compassionate Release Amid COVID-19 Pandemic (June 23, 2020), https://www.durbin.senate.gov/newsroom/press-releases/durbin-grassley-introduce-new-bipartisanlegislation-to-reform-elderly-home-detention-and-compassionate-release-amid-covid-19-pandemic.

217 See Sandeep Dhaliwal, How Mandatory Minimums are Weaponized, N.Y. TIMES (July 1, 2020), https://www.nytimes.com/2020/07/01/opinion/mandatory-minimum-sentences-protest.html ("Reforms to eliminate mandatory minimums and rein in prosecutorial overreaching are vital to comprehensively reforming our overly punitive criminal justice systems, whose harshness disproportionately affects communities of color."); Scott Hechinger, How Mandatory Minimums Enable Police Misconduct, N.Y. TIMES (Sept. 25, 2019), https://www.nytimes.com/2019/09/25/ opinion/mandatory-minimum-sentencing.html (mandatory minimums "insulate police misconduct"); Judge James S. Gwin, Juror Sentiment on Just Punishment: Do the Federal Sentencing Guidelines Reflect Community Values?, 4 HARV. L. \& POL'Y REV. 173, 185-86 (2010) (“Congressional forays into the establishment of mandatory-minimum sentences ... have only further diminished the connection between community sentiment and criminal punishment."). 
At the front end, federal bail reform efforts in Congress have been virtually non-existent. Federal legislators have pushed for states to reform their bail systems while ignoring the federal pretrial detention crisis at their doorstep. ${ }^{218}$ For example, in 2017, Senators Kamala Harris (D-CA) and Rand Paul (R-KY) introduced the Pretrial Integrity and Safety Act to encourage states "to reform or replace the bail system." 219 In an op-ed supporting their legislation, Harris and Paul highlighted the importance of bail reform, but did not once mention the high federal pretrial detention rate or possible reforms, such as eliminating or narrowing the drug presumption as the Judicial Conference has recommended. ${ }^{220}$ Likewise, Senator Bernie Sanders (I-VT) introduced the No Money Bail Act in 2018 to end money bail in the federal system. However, this bill would have had little impact because federal law already specifically prohibits a judge from imposing a financial condition that results in pretrial jailing. ${ }^{221}$ In a heartening development, the House Judiciary Subcommittee on Crime, Terrorism, and Homeland Security held a hearing on federal and state bail reform last fall. ${ }^{222}$ Representative Jerrold Nadler (D-NY) highlighted the rising federal pretrial detention rate and commented that "surely community safety does not justify this trend." ${ }^{223}$ What this hearing portends for future reform is an open question.

At the back end, there is a real danger that momentum for the "second step" of federal drug law reform will stall and there will be no political will to revisit federal mandatory minimums for decades into the future. As President Trump said during a 2020 Super Bowl ad, "I got it done, and the people in this room got it done,"224 suggesting that there is no work left to do. Of course, defense attorneys and reformers should continue to make arguments against mandatory minimums in drug cases, and most certainly will. But they cannot make those arguments alone.

To fill the void left by Congress' inaction, judges should use their discretion at the bail and sentencing stages of a drug case to effectuate reform and reduce mass

218 See Siegler Written Statement, supra note 15, at 1 ("The federal pretrial detention system is in crisis, too, but its problems have been largely overlooked, even by federal legislators.").

219 Kamala Harris \& Rand Paul, To Shrink Jails, Let's Reform Bail, N.Y. Times (July 20, 2017), https://www.nytimes.com/2017/07/20/opinion/kamala-harris-and-rand-paul-lets-reform-bail.html.

220 See id.

221 See 18 U.S.C. $§ 3142$ (c)(2) ("The judicial officer may not impose a financial condition that results in the pretrial detention of the person.").

222 See Administration of Bail by State and Federal Courts: A Call for Reform: Hearing Before the Subcomm. on Crime, Terrorism, and Homeland Security of the H. Comm. on the Judiciary, 115th Cong. (Nov. 14, 2019) [hereinafter House Bail Hearing], https://judiciary.house.gov/calendar/ eventsingle.aspx?EventID=2256.

223 House Bail Hearing, supra note 222, at 51:35.

224 Catherine Kim, Trump's Criminal Justice Record is More Complicated Than He Claims, Vox (Feb. 5, 2020, 12:30 PM), https://www.vox.com/2020/2/5/21124047/trump-speech-sotucriminal-justice-record. 
incarceration. At the front end, they should make evidence-based decisions that account for the fiscal and human costs of pretrial detention and use their considerable discretion to release more people on bond. This includes closely scrutinizing any government request for temporary pretrial detention at the initial appearance hearing and giving little weight to the presumption of detention at the detention hearing. On the back end, judges should lodge categorical policy disagreements with the drug sentencing guideline and the career offender sentencing guideline using Kimbrough's blueprint. At both stages, judges should issue written opinions that highlight the evidence supporting reform.

\section{A. Advancing Bail Reform by Encouraging the Release of More People on Bond}

Judges should work to counteract the BRA's over-detention of people charged with drug offenses without waiting for Congress to change the law. As discussed in Part I, the BRA permits prosecutors to request temporary detention at the initial appearance hearing if the person is charged with a drug offense that has a maximum term of imprisonment of ten years or more. ${ }^{225}$ The BRA also mandates a presumption of detention in those cases. ${ }^{226}$ As discussed in Part II, supra, the legislative history of the drug presumption shows that legislators intended it to apply to "major drug traffickers" with the financial means to flee. Senator Chiles, one of the strongest proponents of the drug presumption, conceded that "[o]ften a person who has been arrested for drug dealing may not be dangerous in the sense that he is likely to rob or kill someone." ${ }^{227}$ Data shows that the presumption is not working as legislators intended, and the Judicial Conference has recommended that Congress eliminate it in most cases. It is unclear when Congress will take action, if ever.

To counteract Congress' dysfunction and promote reform, judges should release more people charged with drug offenses. The pretrial detention rates are simply too high. They do not reflect what legislators intended and they do not promote the BRA's goals. The BRA gives judges ample discretion to make release decisions, even when a person is subject to the presumption. To effectuate higher release rates in drug cases, judges should take two important steps.

First, at the initial appearance stage, judges should closely scrutinize prosecutors' requests for temporary detention in drug cases. The BRA does not require temporary detention in drug cases; it is only triggered "upon motion of the attorney for the Government." 228 The data on rising pretrial detention rates strongly suggest that prosecutors are moving for detention in too many cases. Since 2006, federal prosecutors' national detention request rates have ranged from $60 \%$ to

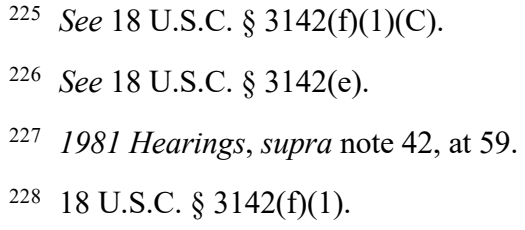


$65 \% .{ }^{229}$ Prosecutors consistently request detention at higher rates than Pretrial Services. ${ }^{230}$ During that same time period, judges responded by detaining more people, and by 2018 their detention rates were within two percentage points of the prosecutors' request rates (61\% and $63 \%$, respectively). ${ }^{231}$ In 2019, judges' detention rates finally leveled off at $61 \%$ even as prosecutors' request rates spiked to $65 \%$, their highest point in the public data. ${ }^{232}$ Rather than being swayed by prosecutors' harsh approach to bond, judges should follow the evidence-based approach suggested in this paper.

Just because prosecutors can move for detention does not mean they should. If prosecutors make a motion for temporary detention, judges should ask them to explain why they are moving for temporary detention, particularly if available information suggests that the person poses a low risk of flight or danger. Especially when the person played a small role in the overall drug operation or has little to no criminal history, a judge should propose release conditions that they believe would reasonably assure the person's safety and appearance, and should ask the prosecutor to consider withdrawing their detention request. If the prosecutor persists in seeking detention the judge is required to detain the person temporarily, but the judge can still remind the prosecutor that temporary detention in a drug case is a discretionary call by the prosecutor. The judge can also emphasize that, under the BRA, release is the norm and detention is the "carefully-limited exception." 233

Second, at the detention hearing stage, judges should give the drug presumption little weight in the overall detention analysis. Judges can explain that the drug presumption is not working as legislators intended by citing the legislative history discussed in Part I, supra, and the AO study discussed in Part III, supra. The legislative history shows that Congress intended the drug presumption to apply to kingpin traffickers, not virtually every person charged with a federal drug offense. Furthermore, legislators intended the presumption to apply to people who were

229 Admin. Off. U.S. Cts., Judicial Business: Federal Pretrial Services Tables, Table H-3A (Sept. 30, 2006-Sept. 30, 2019), https://www.uscourts.gov/data-table-numbers/h-3a.

$230 I d$.

231 See Admin. Off. U.S. Cts., Judicial Business: Federal Pretrial Services Tables, Table H14A (Sept. 30, 2018), https://www.uscourts.gov/sites/default/files/data_tables/jb_h14a_0930.2018.pdf (showing nationwide judicial detention rate of 61\% in 2018); AdmIN. OFF. U.S. CTS., Judicial Business: Federal Pretrial Services Tables, Table H-3A (Sept. 30, 18), https://www.uscourts.gov/sites/ default/files/data_tables/jb_h3a_0930.2018.pdf (showing nationwide AUSA detention request rate of $63 \%$ in 2018).

232 See Admin. Off. U.S. CTS., Judicial Business: Federal Pretrial Services Tables, Table H14A (Sept. 30, 2019), https://www.uscourts.gov/sites/default/files/data_tables/jb_h14a_0930.2019.pdf (showing nationwide judicial detention rate of $61 \%$ in 2019); ADMIN. OFF. U.S. CTS., Judicial Business: Federal Pretrial Services Tables, Table H-3A (Sept. 30, 19), https://www.uscourts.gov/sites/default/ files/data_tables/jb_h3a_0930.2019.pdf (showing nationwide AUSA detention request rate of 65\% in 2019).

233 Salerno, 481 U.S. at 755. 
highly likely to flee. But the AO study shows that the presumption does not correlate with dangerousness or flight risk. ${ }^{234}$ Instead, the presumption over-detains the lowest-risk offenders in the system and has "a negligible effect on the highest-risk defendants." ${ }^{, 235}$ The AO study is a gold mine for judges who want an evidence-based reason to detain fewer people in presumption cases. After all, the federal judiciary's own policy-making body has repeatedly relied on the study to conclude that the presumption sweeps far too broadly and should apply only to drug offenders with serious priors. ${ }^{236}$ Despite the strength of the study and recommendation, only one federal judge has ever cited the AO study in a written opinion ${ }^{237}$ and no judge has cited the Judicial Conference's recommendation. That should also change.

Judicial action is especially important in light of the COVID-19 pandemic that is ravaging federal jails and prisons. ${ }^{238}$ While Attorney General William J. Barr has recommended releasing people from federal prisons to home confinement, "he has directed his federal prosecutors ... to largely oppose releasing people from federal jails," purportedly to advance community safety. ${ }^{239}$ But, as we have argued elsewhere, COVID-19 changes "the safety-of-the-community calculus,"240 especially in light of data showing that people released on bond do not commit new

234 Austin, supra note 17, at 62 ("'[T] he presumption has failed to correctly identify defendants who are most likely to be rearrested for any offense, rearrested for a violent offense, fail to appear, or be revoked for technical violations.").

235 Austin, supra note 17, at 57, 60; Siegler Written Statement, supra note 15, at 14.

236 The Judicial Conference's 2017 recommendation reads as follows (new language underlined): "(3) Subject to rebuttal by the person, it shall be presumed that no condition or combination of conditions will reasonably assure the appearance of the person as required and the safety of the community if the judicial officer finds that there is probable cause to believe that the person committed (A) an offense for which a maximum term of imprisonment of ten years or more is prescribed in the Controlled Substances Act (21 U.S.C. 801 et seq.), the Controlled Substances Import and Export Act (21 U.S.C. 951 et seq.), or chapter 705 of title 46 and such person has previously been convicted of two or more offenses described in subsection (f)(1) of this section, or two or more state or local offenses that would have been offenses described in subsection (f)(1) of this section if a circumstance giving rise to federal jurisdiction had existed, or a combination of such offenses. JUDICIAL CONFERENCE REPORT, supra note 7, at 11. The same language is proposed in the 2020 recommendation. See 2020 Judicial Conference Letter, supra note 8, at Enclosure 2 at 2.

237 See United States v. Sexton, No. 1:19-cr-17, 2019 WL 1318344, at *2 (D. Utah 2019) (quoting the AO study's finding that the drug presumption is "overly broad").

238 See, e.g., Timothy Williams et al., Coronavirus Cases Rise Sharply in Prisons Even as They Plateau Nationwide, N.Y. TimeS (June 10, 2020), https://www.nytimes.com/2020/06/16/us/ coronavirus-inmates-prisons-jails.html.

239 Alison Siegler \& Erica Zunkel, Commentary: Don't Let Chicago's Federal Jail Become the Next Coronavirus Hot Spot, CHI. TRIB. (Apr. 24, 2020), https://www.chicagotribune.com/opinion/ commentary/ct-opinion-coronavirus-jail-cook-county-mcc-20200424-zagv2nvjyzcrvknxbfasusx63astory.html.

$240 I d$. 
crimes or fail to appear in court. ${ }^{241}$ Judges should use their discretion to release more people on bond during the COVID-19 pandemic to protect people charged with crimes and their communities. ${ }^{242}$

\section{B. Advancing Reform by Lodging Policy Disagreements with the Drug Sentencing Guidelines and the Career Offender Guideline}

Judges should also advance reform at the sentencing stage by lodging policy disagreements with the drug guidelines and the career offender guideline and varying from them, even in "mine-run" cases. Judges should articulate their policy disagreements in written opinions. "The published judicial opinion is the "heart of the common law system," "and is "critical to what we understand to be the "law.",243 Moreover, judges "ensure the legitimacy of their decisions by preparing and publishing opinions that explain and justify their reasoning." ${ }^{244} \mathrm{By}$ issuing written opinions that disagree with the guidelines in drug cases, judges "reform sentencing on their own" 245 and develop sentencing common law until Congress changes the laws.

Kimbrough "generated a tsunami to the ongoing sea change in federal sentencing" because, for the first time, the Supreme Court authorized judges to vary from the drug guidelines, even without a showing that the person's individual case was mitigated or extraordinary. ${ }^{246}$ In so doing, the Court put down a post-Booker mutiny by seven federal courts of appeals. ${ }^{247}$ In Spears, the Supreme Court had to step in once again to affirm that it meant what it said in Kimbrough: "That was indeed the point of Kimbrough: a recognition of district courts' authority to vary from the crack cocaine Guidelines based on policy disagreement with them, and not simply based on an individualized determination that they yield an excessive sentence in a particular case." 248

Since Kimbrough, however, only a small number of judges "invok[e] . . policy disagreements with the guidelines and policy statements to help ameliorate the

241 Siegler Written Statement, supra note 15, at 4.

$242 I d$.

243 Martha J. Dragich, Will the Federal Courts of Appeals Perish if They Publish? Or Does the Declining Use of Opinions to Explain and Justify Judicial Decisions Pose a Greater Threat?, 44 Ам. U.L. Rev. 757, 757 (1995) (quoting John Reid, Doe Did Not Sit-The Creation of Opinions by an Artist, 63 Colum. L. ReV. 59, 59 (1963)).

244 Id.

245 Jelani Jefferson Exum, Giving Guidance to the Guidelines, 68 S.C. L. REV. 453, 461 (2017).

246 Bennett, supra note 9, at 892.

247 See Siegler, Rebellion, supra note 122, at 203 \& n. 15.

248 Spears v. United States, 551 U.S. 261, 264 (2009). 
harshness of the guidelines in general, especially in drug cases." ${ }^{249}$ That is troubling in light of Kimbrough and Spears' clear holding that judges have the discretion to disagree with the guidelines on policy grounds, even if it creates "variations between district courts."250 Former federal district court judge Mark Bennett has posited many reasons why judges are reluctant to question the guidelines: fear of reversal, concerns about sentencing uniformity, the guidelines' "strong cognitive anchoring effect," and a consequence of judges giving the Commission "far too much credit" for creating guidelines based on empirical research and prior national experience. ${ }^{251}$

Right after Kimbrough, two appellate judges warned that issuing policy disagreements with the guidelines would have disastrous results. Judge Michael Fisher urged judges not to use their discretion under Kimbrough to "blaze new sentencing trails" because it could "result in disparate sentences and, ultimately, legislative backlash that would strip the federal judiciary of its . . discretion." 252 Judge Thomas Hardiman concurred: "Congress might impose new, detailed statutory penalties that will leave district [court] judges with even less discretion than they possessed in the mandatory Guidelines era." 253 Thankfully, these doomsday predictions have not come to pass.

Contrary to that perspective, Kimbrough both advanced racial justice and is a prime example of how the federal judiciary can promote reform through the common law process.

First, Kimbrough sent a clear message to Congress that the federal judiciary had concerns about the disparity. People had advocated for decades to eliminate the crack/powder disparity, which was seen as racially biased from its inception and perpetuated differential sentencing treatment based on race. ${ }^{254}$ While advocacy

249 Bennett, supra note 9, at 904.

250 Kimbrough, 552 U.S. at 107-08 ("These measures will not eliminate variations between district courts, but our opinion in Booker recognized that some departures from uniformity were a necessary cost of the remedy we adopted."); see also Siegler, Rebellion, supra note 122, at 220-21 (responding to misplaced concerns that increased judicial discretion creates unwarranted sentencing disparities).

251 Bennett, supra note 9, at 906-08.

${ }^{252}$ Id. at 908-09 (citing D. Michael Fisher, Striking a Balance: The Need to Temper Judicial Discretion Against a Background of Legislative Interest in Federal Sentencing, 46 DuQ. L. REV. 65 (2007)).

253 Id. at 913 (citing Thomas M. Hardiman \& Richard L. Heppner Jr., Policy Disagreements with the United States Sentencing Guidelines: A Welcome Expansion of Judicial Discretion or the Beginning of the End of the Sentencing Guidelines?, 50 DuQ. L. REV. 5 (2012)).

254 See, e.g., NAACP, Press Release: NAACP Applauds Steps Taken by US Sentencing Commission to Begin Addressing Crack/Powder Cocaine Sentencing Disparities (Nov. 16, 2007), https://www.naacp.org/latest/naacp-applauds-steps-taken-by-us-sentencing-commission-to-beginaddressing-crack-powder-cocaine-sentencing-disparities/. In the early days, people attacked the disparity by alleging racially selective prosecution in crack cases, but the Supreme Court quelled that 
efforts were of course critical to the Fair Sentencing Act's passage, Congress changed the law only after the Supreme Court concluded in Kimbrough that the disparity was based on erroneous assumptions, not evidence. ${ }^{255}$ Approximately two years after Kimbrough, Congress reduced the disparity in the Fair Sentencing Act and the Commission amended the drug guidelines to reflect the new law. ${ }^{256}$ During debate on the Fair Sentencing Act, the House Committee on the Judiciary cited Kimbrough, noting that the Court had made "a fundamental change in how Federal judges apply sentencing guidelines regarding cocaine" and that federal judges could now impose "more reasonable sentences" in crack cases. ${ }^{257}$

Second, Kimbrough confirmed that federal district court judges had the discretion to disagree with the disparity, and judges used this discretion to reduce sentences accordingly. Kimbrough thus provides the federal judiciary with a blueprint for continued reform of the drug guidelines and the career offender guideline.

\section{Categorical Policy Disagreements with the Drug Sentencing Guidelines}

Judges should promote reform by categorically disagreeing with the drug guidelines in written opinions. As discussed above, the Supreme Court explicitly approved this approach in Kimbrough and Spears. Moreover, policy disagreements are "healthy" and promote "the process of constantly improving" the guidelines, which "were intended to be evolutionary in nature." 258 Policy disagreements are particularly important when the Commission and Congress are not engaging in dialogue about sentencing policy, and the Commission simply "aaccept[s] and incorporate[s]' the mandatory minimums 'wholesale into the guideline structure without the Commission's independent analysis." 259 One judge described issuing policy disagreements with the drug guidelines as an imperative: "Critically evaluating the crack/cocaine ratio in terms of its fealty to the purposes of the Sentencing Reform Act is not optional. It is not something that a judge has discretion to do or not do. The Supreme Court in Kimbrough and Spears held that an advisory

litigation strategy by setting an insuperable discovery standard in United States v. Armstrong, 517 U.S. 456 (1996).

255 Kimbrough, 522 U.S. at 95-96.

256 U.S. SENTENCING COMM’n, REPORT tO THE CONGRESS: IMPACT OF THE FAIR SENTENCING ACt OF 2010, at 5-6 (Aug. 2015), https://www.ussc.gov/sites/default/files/pdf/news/congressionaltestimony-and-reports/drug-topics/201507_RtC_Fair-Sentencing-Act.pdf\#page=8.

257 H.R. REP. No. 111-670, pt. 1, at 14 (2010).

258 United States v. Hayes, 948 F. Supp. 2d 1009, 1031 (N.D. Iowa 2013); United States v. Diaz, 2013 WL 322243 , at *8.

259 Diaz, 2013 WL 322243, at *16. 
Guideline system required it." ${ }^{260}$ Finally, it is imperative for judges to highlight the racial disparities that mandatory minimums and the drug guidelines have produced for the last three decades. ${ }^{261}$

Kimbrough focused on the problems with the crack cocaine guideline, but the same arguments apply to other drugs as well. For example, judges have railed against the drug guidelines' misguided use of drug type and quantity as a proxy for culpability. "The structural flaw is easily traced. It is rooted directly in the fateful choice by the original Commission to link the Guidelines ranges for all drug trafficking defendants to the onerous mandatory minimum penalties in the AntiDrug Abuse Act of 1986 . . . that were expressly intended for only a few." ${ }^{262}$ Former Judge Bennett points out that "a whopping $83.1 \%$ of the meth defendants in federal court faced a mandatory minimum sentence even though the vast majority were not kingpins," because "quantity is a poor proxy for most meth defendants' criminal culpability." 263 The drug guidelines also call for increased punishment in methamphetamine cases based on purity. This distinction is not based on empirical evidence, careful study, or national experience. "While it may seem logical to punish a pure substance more than [a] mixed substance, there is no support in the legislative history to explain the formula underlying greater methamphetamine purity to greater months of imprisonment." 264 These are all legitimate bases for categorical policy disagreements with the drug guidelines.

Judges have the discretion to vary from the drug guidelines based on a categorical policy disagreement, even in a "mine-run" case, and then consider

260 United States v. Whigham, 754 F. Supp. 2d 239, 247 (D. Mass. 2010); see also Exum, supra note 245 , at 463 (describing conversations with judges in which they expressed "highly critical perceptions ... of the drug Guidelines," such as "drug sentences are out of control," "drug Guidelines are out of whack," and "Guidelines are obsessed with drug quantities").

261 Rakoff, supra note 29 (“And whom are we locking up? Mostly young men of color.”); Radley Balko, Opinion: There's Overwhelming Evidence that the Criminal Justice System is Racist. Here's the Proof., WASH. Post (June 10, 2020), https://www.washingtonpost.com/graphics/2020/opinions/ systemic-racism-police-evidence-criminal-justice-system/.

262 Diaz, 2013 WL 322243 at*1; United States v. Cabrera, 567 F. Supp. 2d 271, 275 (D. Mass. 2008) (varying downward and rejecting the cocaine guideline because of "the over-emphasis on quantity and under-emphasis on role in the offense").

263 Bennett, supra note 9, at 902. Methamphetamine offenses continue to be charged and sentenced at a higher rate than all other drug offenses. 2019 SourCEBOOK, supra note 13, at 108, Table D-1 (methamphetamine offenses constituted 42\% of all drug offenses in Fiscal Year 2019). They are also the most severely punished, with an average sentence of 95 months. Id. at 124, Table D-3.

264 Hayes, 948 F. Supp. 2d at 1025; see also id. at 1031 (concluding that it is appropriate to reduce "the penalty by one third for methamphetamine offenses in response to the fundamental problems with the methamphetamine Guidelines range"). 
aggravating and mitigating arguments under $\S 3553(a) .{ }^{265}$ Judges who have lodged categorical policy disagreements with the drug guidelines have fashioned various remedies for determining what kind of sentencing variance is appropriate. For crack cocaine, some judges have decided to apply a 1-to-1 ratio in all cases, in spite of Congress' adoption of an 18-to-1 ratio. ${ }^{266}$ For methamphetamine, some judges have reduced the guidelines by one third "to account for the policy disagreement." 267

Even with judge-crafted remedies and the Commission's 2014 reduction of the drug quantity levels across the board, ${ }^{268}$ the drug guidelines remains flawed and in need of reform. As it is, judges vary below the guidelines in drug cases approximately $33 \%$ of the time, ${ }^{269}$ excluding substantial assistance departures. This is a clear indication that judges believe that, in at least one third of all federal cases, the drug guidelines do not properly calibrate sentencing ranges and leads to sentences that do not fulfill $\S 3553$ (a)'s purposes.

\section{Categorical Policy Disagreements with the Career Offender Sentencing Guideline}

It is imperative that judges also issue categorical policy disagreements with the career offender guideline, especially for people with prior records for drugs instead of violence. The career offender guideline is another byproduct of the War on Drugs.

265 See Hayes, 948 F. Supp. 2d at 1031 ("[A]fter reducing the Guidelines range by one third to account for the policy disagreement, I will reserve the ability to adjust the figure upwards and downwards as I weigh the 18 U.S.C. § 3553(a) factors.”).

266 See, e.g., Whigham, 754 F. Supp. 2d at 246 ("I will apply a 1:1 ratio for all crack cocaine sentencings.”); United States v. Gully, 619 F. Supp. 2d 633, 637 (N.D. Iowa 2009); United States v. Lewis, 623 F. Supp. 2d 42, 45 (D.D.C. 2009).

267 Hayes, 948 F. Supp. 2d at 1031.

268 In 2014, the Commission voted unanimously to lower the drug guidelines "in order to help control federal prison costs and populations, ensure fair and just sentences, and protect public safety." U.S. Sentencing Comm'n, Sensible Sentencing Reform: The 2014 Reduction of Drug Sentences (2014), https://www.ussc.gov/sites/default/files/pdf/research-and-publications/backgrounders/profile 2014drugamendment.pdf. While this across-the-board reduction was a step in the right direction, it did nothing to change or fix the underlying problems with the drug guidelines. See Diaz, 2013 WL 322243, at *1 (disagreeing with the drug guidelines on policy grounds and urging the Commission to " de-link' the drug trafficking Guidelines ranges from the 1986 Act's weight-driven mandatory minimum sentences and use its resources, knowledge, and expertise to fashion fair sentencing ranges for drug trafficking offenses."). On the upside, data shows that the reduction did not lead to an increase in recidivism. The Commission found there was no statistically significant difference in the recidivism rates of people released early and a comparable group of people who served their full sentences. See U.S. Sentencing Comm'n, Retroactivity and Recidivism: The Drugs Minus Two Amendment 1 (July 2020), https://www.ussc.gov/sites/default/files/pdf/research-and-publications/research-publicat ions/2020/20200708Recidivism-Drugs-Minus-Two.pdf. This finding was consistent across all drug types. See id. at 6.

2692019 ANNUAL REPORT, supra note 13, at 123. 
It recommends astronomical sentences for people who have been convicted of a drug trafficking offense and who have two or more drug trafficking offenses on their record (referred to as "drug trafficking only" career offenders). In 2016, the Commission recommended that Congress amend the career offender statutory directive so that it no longer includes those who qualify as career offenders based solely on drug trafficking offenses. ${ }^{270}$ In theory, this should be a straightforward reform because it is supported by ample evidence, but Congress has failed to take action. Until Congress does, judges should promote reform by disagreeing with the career offender guideline on policy grounds in "drug trafficking only" career offender cases. To develop sentencing common law, judges should issue written opinions that discuss the evidence and explain the problems with applying the career offender guideline in such cases.

The career offender provision applies to a person who commits a "controlled substance" offense or a "crime of violence" after two prior felony convictions for either one of those offenses. ${ }^{271}$ The guideline has draconian consequences: it increases all career offenders to Criminal History Category ("CHC") VI and to offense levels at or near the statutory maximum penalty of the offense of conviction. ${ }^{272}$ The guideline defines a "controlled substance" offense broadly. ${ }^{273}$ Likewise, career offender predicate convictions bafflingly include misdemeanors and convictions that result in no jail or prison time. ${ }^{274}$ As a result, very low-level offenders who have never before been incarcerated face extremely long sentences if they fall within the career offender guideline's net.

The career offender guideline is the Commission's response to a part of the SRA that requires sentences for recidivist offenders to be "at or near the maximum term." 275 Congress was particularly concerned with "repeat drug traffickers," noting during debate on the SRA that drug trafficking was an "extremely lucrative" enterprise "carried on to an unusual degree by persons engaged in continuing

2702016 CAREER OFFENDER REPORT, supra note 12, at 3.

271 U.S. Sentencing Guidelines Manual § 4B1.1(a) (U.S. Sentencing Comm’n 2018).

272 U.S. Sentencing Guidelines Manual § 4B1.1(b) (U.S. Sentencing Comm’n 2018)..

273 "The term 'controlled substance offense' means an offense under federal or state law, punishable by imprisonment for a term exceeding one year, that prohibits the manufacture, import, export, distribution, or dispensing of a controlled substance ... or the possession of a controlled substance ... with the intent to manufacture, import, export, distribute, or dispense." U.S. SENTENCING Guidelines MANuAL § 4B1.2(b) (U.S. SENTENCING COMM’N 2018).

274 To qualify as a career offender predicate, the prior felony conviction must be "a prior adult federal or state conviction for an offense punishable by death or imprisonment for a term exceeding one year, regardless of whether such offense is specifically designated as a felony and regardless of the actual sentence imposed." U.S. Sentencing Guidelines Manual § 4B1.2(b) app. n.1 (U.S. SENTENCING COMM'N 2018).

27528 U.S.C. § 994(h) (2006). 
patterns of criminal activity." ${ }^{276}$ As with the BRA and the 1986 Act, Congress was once again in full War-on-Drugs mode - more focused on being "tough on crime" than on the practical consequences of requiring the Commission to set sentences for recidivist drug offenders at or near the statutory maximum.

The Commission made things worse when it formulated the career offender guideline. It did not "follow the plain terms of this statutory directive" and has since "expanded the list of qualifying drug offenses by adding numerous state and federal drug offenses to those listed in $\S 994(\mathrm{~h}) . "{ }^{277}$ Moreover, by pegging the career offender guideline to the offense's statutory maximum, the Commission did not consider whether the resulting sentences satisfied $\S$ 3553(a)'s purposes of punishment or the "parsimony provision." ${ }^{278}$ Finally, because most drug offenses carry a maximum penalty of life imprisonment, people convicted of drug offenses often face much higher statutory maximum penalties than those who are convicted of violent offenses. ${ }^{279}$ For example, nearly $80 \%$ of "violent only" 280 career offenders faced statutory maximums of less than 25 years, which bizarrely results in a lower offense level under the career offender guideline. ${ }^{281}$

The Commission's data demonstrate that the career offender guideline is overly severe, especially in drug cases. Not surprisingly, the career offender provision impacts people convicted of drug offenses most severely. Of the career offenders sentenced in Fiscal Year 2018, the overwhelming majority-78\%-were convicted of drug offenses. ${ }^{282}$ In approximately $93 \%$ of these cases, the person's career offender status increased their guideline range. ${ }^{283}$ Nearly $50 \%$ of career offenders saw an increase in both their final offense level and their $\mathrm{CHC}^{284}$ As the Commission itself has observed, the career offender provision has "resulted in some of the most severe penalties imposed under the guidelines," 285 with "the greatest

276 S. REP. No. 98-225 (1983).

277 United States v. Newhouse, 919 F. Supp. 2d 955, 971 (N.D. Iowa 2013) (citing Amy BaronEvans et al., Deconstructing the Career Offender Guideline, 2 CHARlotTE L. REv. 39, 53-56 (2010)).

278 Newhouse, 919 F. Supp. $2 \mathrm{~d}$ at 973.

2792016 CAREER OFFENDER REPORT, supra note 12, at 31.

280 This refers to people who are classified as career offenders because they are charged with a "crime of violence" and have two prior felony "crime of violence" convictions. See id. at 27.

281 Id. at 32.

282 U.S. Sentencing Comm'n, Quick FaCts-CAREer OfFEnders-Fiscal Year 2018 (2018), https://www.ussc.gov/sites/default/files/pdf/research-and-publications/quick-facts/Quick_ Facts_Career_Offender_FY18.pdf.

${ }^{283} I d$.

$284 I d$.

285 U.S. Sentencing Comm’n, Fifteen Years of Guidelines Sentencing: An Assessment of How Well the Federal Criminal Justice System is Achieving the Goals of Sentencing Reform 133 (Nov. 2004) [hereinafter FIFTEEN YEAR REPORT], https://www.ussc.gov/sites/default/ 
impact on the offenders in the drug trafficking only category." 286 Because their sentences are so lengthy, career offenders now account for over $11 \%$ of the total BOP population, ${ }^{287}$ even though career offender cases only constitute $2.5 \%$ of the federal sentencing docket. ${ }^{288}$

The career offender guideline also results in disturbing racial disparities. The Sentencing Commission's Fifteen Year Report highlighted the career offender guideline's "unwarranted adverse impacts" on people of color. ${ }^{289}$ In particular, the Fifteen Year Report found that Black people are more often subject "to the severe penalties required by the career offender guideline" than similarly-situated White people because of "the relative ease of detecting and prosecuting offenses that take place in open-air drug markets, which are most often found in impoverished minority neighborhoods." 290 That reality puts Black people at a "higher risk of conviction for a drug trafficking crime," 291 and makes them more likely to have drug convictions on their record in the first place. The statistics bear this out. In Fiscal Year 2018, $61.6 \%$ of career offenders were Black. ${ }^{292}$ The Commission and the Supreme Court have recognized the pernicious effect of even the perception of sentencing disparities based on race, because it fosters "disrespect for and lack of confidence in the criminal justice system. ${ }^{, 293}$

The foregoing makes clear that judges should issue categorical policy disagreements with the career offender guideline for "drug trafficking only" career offenders, regardless of the mitigating or aggravating facts of the case. There are a number of evidence-based policy reasons judges can give for issuing belowguideline sentences in career offender drug cases.

files/pdf/research-and-publications/research-projects-and-surveys/miscellaneous/15-yearstudy/15_year_study_full.pdf.

2862016 CAREER OFFENDER REPORT, supra note 12, at 31.

287 Id. at 18.

2882019 ANNUAL REPORT, supra note 13, at 77, Table 23.

289 FIFTEEN YeAR REPORT, supra note 285, at 134.

290 Id. at $134-35$.

291 Id. at 134.

292 See U.S. SENTENCING COMm’N, Quick FACTS: CAREer OfFenders, https://www.ussc.gov/ sites/default/files/pdf/research-and-publications/quick-

facts/Quick_Facts_Career_Offender_FY18.pdf.

293 Kimbrough, 552 U.S. at 98 (quoting U.S. Sentencing Comm'n, Report to Congress: Cocaine And Federal Sentencing Policy 103 (May 2002)); see also Fifteen Year Report, supra note 285, at 134 ("America's special concern with racial justice helped lead to the creation of a sentencing system based on racially neutral rules. Evaluating the success of this system at eliminating any vestige of discrimination must be a central component of evaluating the guidelines."). 
First, the career offender guideline is not the product of "careful study, empirical research, or national experience." ${ }^{294}$ Amy Baron-Evans, who was until recently the Federal Defender's Chief Sentencing Resource Counsel, comprehensively "deconstructed" the numerous problems with the career offender guideline in a 2010 paper. ${ }^{295}$ The typical profile of a career offender is someone who commits a low-level federal drug offense and has two prior state convictions for minor drug offenses. ${ }^{296}$ Before the guidelines were enacted, a person with two prior drug offenses on his record who was charged federally with possessing with intent to distribute 50 grams of heroin would be facing 37 to 46 months. ${ }^{297}$ That is approximately the same sentence the person would face under the guidelines without application of the career offender provision. ${ }^{298}$ Under the career offender guideline, however, the person's guideline range skyrockets to 210 to 262 months. ${ }^{299}$ Because Congress directed the Commission to set career offender guideline ranges at or near the statutory maximum, the Commission did not rely on pre-guidelines sentencing practices or employ an empirical approach when it formulated the career offender guideline. ${ }^{300}$ As a result, under Kimbrough's rubric, the career offender guideline "cannot be assumed to be a 'rough approximation' ... of $\S 3553$ (a)'s objectives." 301 The guideline also "defines the class of career offenders . . . much more broadly than the statute requires." ${ }^{302}$ In particular, it includes numerous drug offenses not listed in the relevant statute, providing only a "blanket post-hoc justification" for doing so. ${ }^{303}$

Next, judges should account for the fact that the Commission now disagrees with applying the career offender guideline to people who are "drug trafficking only" career offenders and has recommended that Congress remove them from the relevant statute. ${ }^{304}$ In a 2016 report to Congress, the Commission concluded that the guideline should "differentiate between career offenders with different types of criminal records, and is best focused on those offenders who have committed at least

294 Amy Baron-Evans et al., Deconstructing the Career Offender Guideline, 2 CHARLOTtE L. REV. 39, 53-56 (2010).

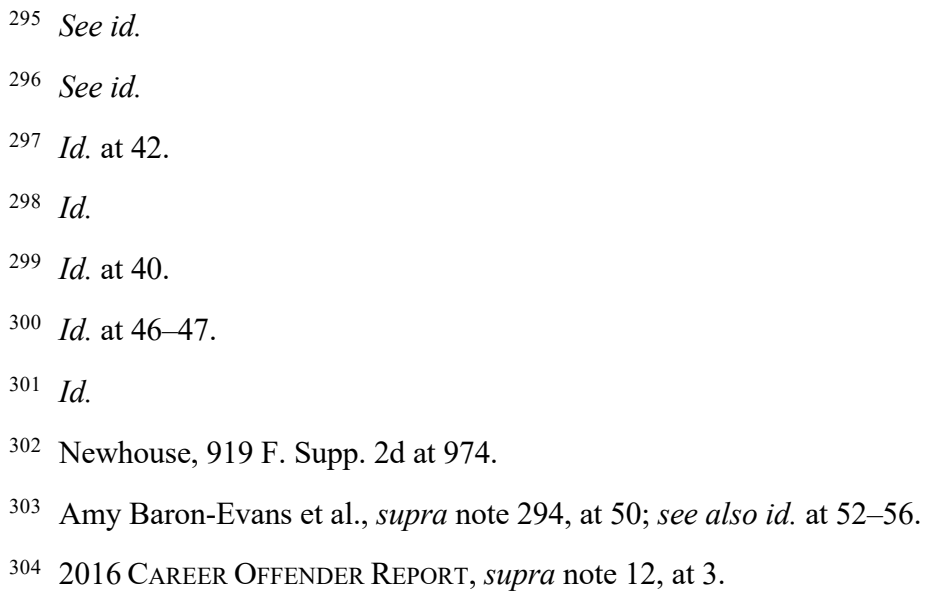


one "crime of violence." ${ }^{305}$ The Commission emphasized that reforming the career offender directive to exclude "drug trafficking" only career offenders "would help ensure that federal sentences better account for the severity of the offenders' prior records, protect the public, and avoid undue severity for certain less culpable offenders." $" 306$

In its report, the Commission acknowledged several additional problems with the career offender guideline. First, it pegs punishment to the offense's statutory maximum, which can lead to absurd results. ${ }^{307}$ For most federal drug offenses, the statutory maximum - determined by the 1986 Act - is life in prison. ${ }^{308}$ As a result, "[c]ontrary to what might be expected," the career offender guideline has "a significantly greater sentencing impact" on drug-trafficking only career offenders because drug offenses have much higher statutory maximum penalties than many violent offenses. ${ }^{309}$ For example, people who are convicted under the "primary drug trafficking statute"-21 U.S.C. $\S 841$-face a statutory maximum penalty of life imprisonment, which correlates with the highest possible career offender offense level under the guidelines - level 37. ${ }^{310}$ Coupled with Criminal History Category VI and without any departures and adjustments, that yields a guideline range of 36 years to life. ${ }^{311}$ On the flip side, the federal offense of robbery-also a career offender predicate - has a statutory maximum penalty of 20 years and therefore the career offender offense level is 32 under the guidelines and the resulting guideline range is 210 to 262 months. ${ }^{312}$ This result makes no sense. Second, the Commission found that "drug trafficking only" career offenders are not "meaningfully different" from other people convicted of federal drug offenses who are sentenced under the drug guidelines. ${ }^{313}$ Thus, they should not "categorically be subject to the significant increases in penalties required by the career offender directive." 314 One example of this is that "drug trafficking only" career offenders recidivate at a lower rate than

$305 I d$.

306 Id.

307 Id.

308 See Anti-Drug Abuse Act of 1986, Pub. L. No. 99-570, 100 Stat. 3207 (codified as amended at 21 U.S.C. $\S 841$ (1986)).

309 Amy Baron-Evans et al., supra note 294, at 47.

3102016 CAREER OFFENDER REPORT, supra note 12, at 8.

311 See id.; U.S. Sentencing Guidelines Manual, Sentencing Table (U.S. Sentencing COMM'N 2018).

3122016 CAREer OfFENDER Report, supra note 12, at 8; see U.S. SENTENCING GUIDELINES Manual § 4B1.1 (U.S. Sentencing Comm'N 2018); U.S. Sentencing Guidelines Manual, SEnTENCING TABle (U.S. SENTENCING COMM’N 2018).

3132016 CAREER OFFENDER REPORT, supra note 12, at 27.

314 Id. 
career offenders who are charged with a "crime of violence" or have such an offense on their record. ${ }^{315}$

The Commission did not make its recommendation lightly. Its exhaustive 64page report analyzed data and incorporated feedback from judges, practitioners, academics, and other interest groups. ${ }^{316}$ The report was sparked in part by "growing criticisms" about the career offender guideline and the resulting "overly severe penalties" for certain career offenders, which led to "increased departures and variances from the guidelines." ${ }^{117}$ As an example, in United States v. Newhouse, the district court sentenced a "drug trafficking only" career offender to a greatly-reduced sentence, explaining in a written opinion that the guideline range went from 70 to 87 months to "a staggering and mind-numbing 262 to 327 months" on the basis of two prior drug convictions that arose out of a single drug raid. ${ }^{318}$ This is exactly the sort of judicial feedback loop that the Supreme Court envisioned in Rita. ${ }^{319}$

After the report, judges find themselves in a "space in which the Commission disagrees with its own Guidelines as applied" for "drug trafficking only" career offenders, with no timeline for when Congress might act on the Commission's reform recommendation. ${ }^{320}$ Legislators need to hear from judges. So far, judges' criticisms of the career offender guideline in "drug trafficking only" cases have largely focused on its application in an individual case, ${ }^{321}$ with some also

315 Id. at 3, 26.

316 See id. at 7.

317 Id. at 11; see also, e.g., United States v. Pruitt, 502 F.3d 1154, 1172 (10th Cir. 2007) ("[D]istrict courts should not be overly shy about concluding that particular defendants, even if thirdtime drug sellers, do not have the profile Congress and the Commission had in mind when they directed that sentences for career drug offenders be set at or near the top of the statutory range."). The Commission's 2016 report notes that "courts were most likely to depart or vary when sentencing offenders in the drug trafficking only pathway, often at the request of the government." 2016 CAREER OFFENDER REPORT, supra note 12, at 44.

318 United States v. Newhouse, 919 F. Supp. 2d 955, 958 (2013).

319 See Rita, 551 U.S. at 350 ("The statutes and the Guidelines themselves foresee continuous evolution helped by the sentencing courts ... in that process.").

320 United States v. Henshaw, 2018 WL 3240982, at*6-7 (S.D. Ill. 2018) (concluding that the career offender guideline's "categorical treatment of drug trafficking only offenders as severely as those who have a history of violence is unjust, results in sentences that are unduly harsh for the former, and therefore fails to promote the goals of sentencing.").

321 On the "as applied" point, judges have noted how the career offender guideline "creates unwarranted uniformity because it lumps together for identical treatment defendants with vastly different criminal histories." United States v. Dixon, 2016 WL 4492843, at *3 (M.D. Ala. 2016). It also does not distinguish between prior convictions "based on how long ago they happened, the quantity of drug involved, whether the defendant played a major or minor role in a prior offense, whether anyone was injured in the offense, or other factors relevant to assessing the seriousness of a defendant's criminal history." Id. 
acknowledging "a quasi-categorical policy disagreement with it when applied to low-level, non-violent drug addicts." ${ }^{322}$

Judges' criticisms up to this point fall short and understate the problems with the career offender guideline. Judges should not be imposing high sentences under a guideline with which the Commission itself disagrees. Instead, judges should categorically reject the career offender guideline in all "drug trafficking only" career offender cases on policy grounds, before turning to an individualized analysis of the $\S 3553$ (a) factors. More specifically, judges should take the following steps at sentencing: (1) calculate the guidelines applying the career offender provision, to comply with Booker and its progeny; (2) lodge a categorical policy disagreement with the career offender guideline, citing the Commission's 2016 Report; (3) calculate the guidelines that would apply notwithstanding the career offender guideline; and (4) analyze the $\S 3553$ (a) factors to reach a sentence that is "sufficient, but not greater than necessary" to achieve the purposes of sentencing. ${ }^{323}$ Judges should then explain the rationale for their policy disagreement in a written opinion to shape the sentencing common law and provide feedback to the Commission and Congress.

\section{CONCLUSION}

Given that Congress is perennially mired in tough-on-crime politics, substantive federal drug law reform is highly unlikely for the foreseeable future. Federal judges must not wait for Congress to change the law. Instead, judges must acknowledge that the federal drug laws were enacted at the height of the War on Drugs, have led to significant racial disparities, and have contributed to the mass incarceration of people of color. In light of these realities, judges should use the substantial discretion vested in them to promote reform at both ends of the detention crisis, at bail and at sentencing. Judges should release more people on bail, reduce more sentences based on categorical disagreements with the drug guidelines and the career offender guideline, and write more opinions on these pivotal issues. If judges use their discretion in this way they can reduce racial disparities, ameliorate mass incarceration, and perhaps even prompt Congress to take more decisive action.

322 Newhouse, 919 F. Supp. 2d at 974 ("I do not have a categorical policy disagreement with the Career Offender guideline" because in spite of its "identified flaws," it sometimes "arrives at a sentencing range that fulfills the overarching purpose of sentencing"); see also Whigham, 754 F. Supp. $2 \mathrm{~d}$ at 248 (noting that there is "no question that the career offender guidelines are flawed" and varying below the guidelines in part because Whigham - "a petty dealer, making little or no money" — did not "remotely fit the portrait" of who Congress envisioned would be sentenced as a career offender). There are approximately twelve opinions in which judges disagree with the career offender guideline on policy grounds.

32318 U.S.C. $\S 3553(a)$ (2018). 